\title{
The Basse-Terre Island of Guadeloupe (Eastern Caribbean, France) and Its Volcanic-Hydrothermal Geodiversity: A Case Study of Challenges, Perspectives, and New Paradigms for Resilience and Sustainability on Volcanic Islands
}

\author{
Roberto Moretti $^{1,2, *}$, Séverine Moune ${ }^{1,2,3}$, David Jessop ${ }^{1,2,3} \mathbb{D}$, Chagnon Glynn ${ }^{1}$, Vincent Robert ${ }^{1,2} \mathbb{D}$ \\ and Sébastien Deroussi ${ }^{1,2}$ \\ 1 Institut de Physique du Globe de Paris, Université de Paris, UMR 7154 CNRS, 75238 Paris, France; \\ moune@ipgp.fr (S.M.); jessop@ipgp.fr (D.J.); glynn@ipgp.fr (C.G.); robertv@ipgp.fr (V.R.); \\ deroussi@ipgp.fr (S.D.) \\ 2 Observatoire Volcanologique et Sismologique de Guadeloupe, Institut de Physique du Globe de Paris, \\ 97113 Guadeloupe, France \\ 3 IRD, OPGC Laboratoire Magmas et Volcans, Université Clermont Auvergne, 12, \\ 63000 Clermont-Ferrand, France \\ * Correspondence: moretti@ipgp.fr
}

check for updates

Citation: Moretti, R.; Moune, S.; Jessop, D.; Glynn, C.; Robert, V.; Deroussi, S. The Basse-Terre Island of Guadeloupe (Eastern Caribbean, France) and Its Volcanic-Hydrothermal Geodiversity: A Case Study of Challenges, Perspectives, and New Paradigms for Resilience and Sustainability on Volcanic Islands. Geosciences 2021, 11, 454. https:// doi.org/10.3390/geosciences11110454

Academic Editors: Javier Dóniz Páez and Jesus Martinez-Frias

Received: 30 August 2021

Accepted: 25 October 2021

Published: 2 November 2021

Publisher's Note: MDPI stays neutral with regard to jurisdictional claims in published maps and institutional affiliations.

Copyright: (c) 2021 by the authors. Licensee MDPI, Basel, Switzerland. This article is an open access article distributed under the terms and conditions of the Creative Commons Attribution (CC BY) license (https:// creativecommons.org/licenses/by/ $4.0 /)$.

\begin{abstract}
The volcanic-hydrothermal geo-diversity of the Basse-Terre Island of Guadeloupe archipelago (Eastern Caribbean, France) is a major asset of the Caribbean bio-geoheritage. In this paper, we use Guadeloupe as a representative of many small island developing states (SIDS), to show that the volcanic-hydrothermal geodiversity is a major resource and strategic thread for resilience and sustainability. These latter are related to the specific richness of Guadeloupe's volcanic-geothermal diversity, which is de facto inalienable even in the wake of climate change and natural risks that are responsible for this diversity, i.e., volcanic eruptions. We propose the interweaving the specificity of volcanic-geothermal diversity into planning initiatives for resilience and sustainability. Among these initiatives research and development programs focused on the knowledge of geodiversity, biodiversity and related resources and risks are central for the long-term management of the water resource, lato sensu. Such a management should include a comprehensive scientific observatory for the characterization, exploration, and sustainable exploitation of the volcanic-hydrothermal geodiversity alongside planning for and mitigating geophysical risks related to sudden volcanicinduced phenomena and long-term systemic drifts due to climate change. The results of this exercise for Guadeloupe could typify innovative paths for similar SIDS around their own volcanichydrothermal geodiversity.
\end{abstract}

Keywords: andesitic volcanism; hydrothermal systems; unrest; geodiversity; resilience; geothermal energy; sustainability

\section{Introduction}

Volcanic islands are characterized by diverse biophysical (e.g., volcanic or atoll island), geographical (e.g., remoteness), cultural, and political landscapes. Most of them are small island developing states (SIDS) that, compared to developed mainland states, experience challenges and risks that result from the relatively small land area, population, and economy. In particular, the small area and population size make them vulnerable to extreme events, such as cyclones, earthquakes, tsunamis, and volcanic eruptions. These phenomena may cause widespread damage even across the entire country and cause disproportionate economic losses, in absolute and with respect to gross domestic product. Any mitigation and adaptation efforts are obviously constrained by limitations in the availability of local resources. This implies that such territories must develop a sustainable and integrated 
economic model able to provide the required adaptation to both climate change and geophysical risks. Because local economies rely heavily on natural resources for tourism, volcanic islands are favored because of the great attractive power and scenic value offered by volcanic deposits, active volcanoes, and, particularly in the case of subduction zone volcanoes, the presence of extensive hydrothermal systems. All these elements, however, add pressure to fragile ecosystems that are slow to recover from natural disasters. So, an appropriate adaptation to volcanic risks and their interactions with climate change issues must be considered to foster the resilience and plan sustainable development of SIDS.

Among these islands, Guadeloupe (Eastern Caribbean, France; Figure 1) is highly recognized for its biodiversity and is also a hotspot of geodiversity, that brings together carbonate platform, coral reefs (both active and fossil), mangroves, tropical karsts, a great variety of volcanic deposits, on-shore and submarine thermal springs, and an active volcano presently in hydrothermal stage (Figure 2). The biodiversity of an ecosystem derives in part from its underlying geology and the majority of biological species remain undescribed. Therefore, continuous update, monitoring, and preservation of the assessed geodiversity is also imperative for the maintenance of biodiversity. In 2002, with the promulgation of the Law on Democracy of Proximity, the French parliament empowered the juridical instruments that "assures the conception, the animation, and the evaluation of the natural heritage inventory, which includes the ecological, faunal, floral, geological, mineral, and paleontological resources" (De Wever et al. 2007 [1]). In virtue of this law, the inventory of geological heritage was then officially launched in 2007 and Guadeloupe selected as a test case (Chauvet et al. 2008 [2]) to assess the geodiversity from which could be identified and extracted a geoheritage, that is, the ensemble of geological features and sites that are naturally or culturally important and valuable for human appreciation (Brocx and Semeniuk, 2007 [3]). Since then, stakeholders have carefully surveyed and assessed the Guadeloupe geodiversity, including the volcanic-hydrothermal one (Bès de Berc et al. 2007; Bézèlgues-Courtade and Bes-De-Berc, 2007; 2008; and Conseil Régional de Guadeloupe, 2013 [4-6]). More than 30 remarkable sites have been validated, which are referenced into the i-Geotope database (http:/ /igeotope.brgm.fr, accessed on 30 September 2021) and the Inventaire National du Patrimoine Géologique (INPG) (De Wever et al. 2014 [7]), with update activities in progress (e.g., Mazabraud, 2019 [8]). 


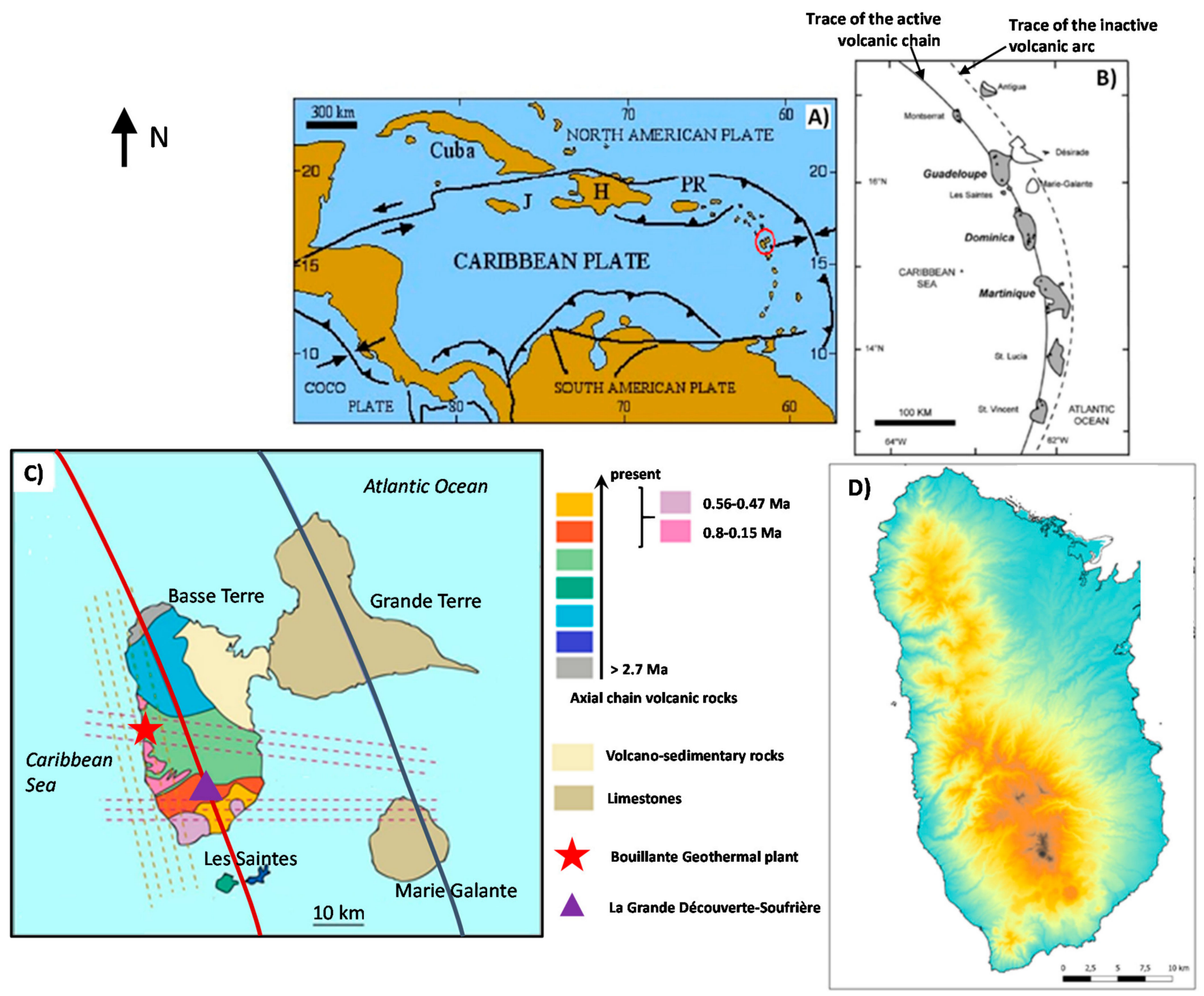

Figure 1. Geographical, morphological, and geological context of the Basse-Terre Island (Guadeloupe) in the Lesser Antilles. (A) Tectonic context of the Caribbean area, with indicated the Guadeloupe island (red ellipse). (B) The Lesser Antilles arc; in grey volcanic islands, in white carbonatic islands (see also Feuillet et al. 2002 [9]). (C) Simplified lithological sketch of the Guadeloupe archipelago with volcanic units and main faults (dashed lines) of the Basse-Terre Island (modified from Komorowski et al. 2005; Lachassagne et al. 2009; and Raguenuel et al. 2019). (D) Color relief of the Basse-Terre Island based on a digital elevation model (data from Institut national de l'information géographique et forestière, https:/ / geoservices.ign.fr / accessed on 30 September 2021) and showing volcanic centres aligned along a NNW-SSE tectonic feature. 

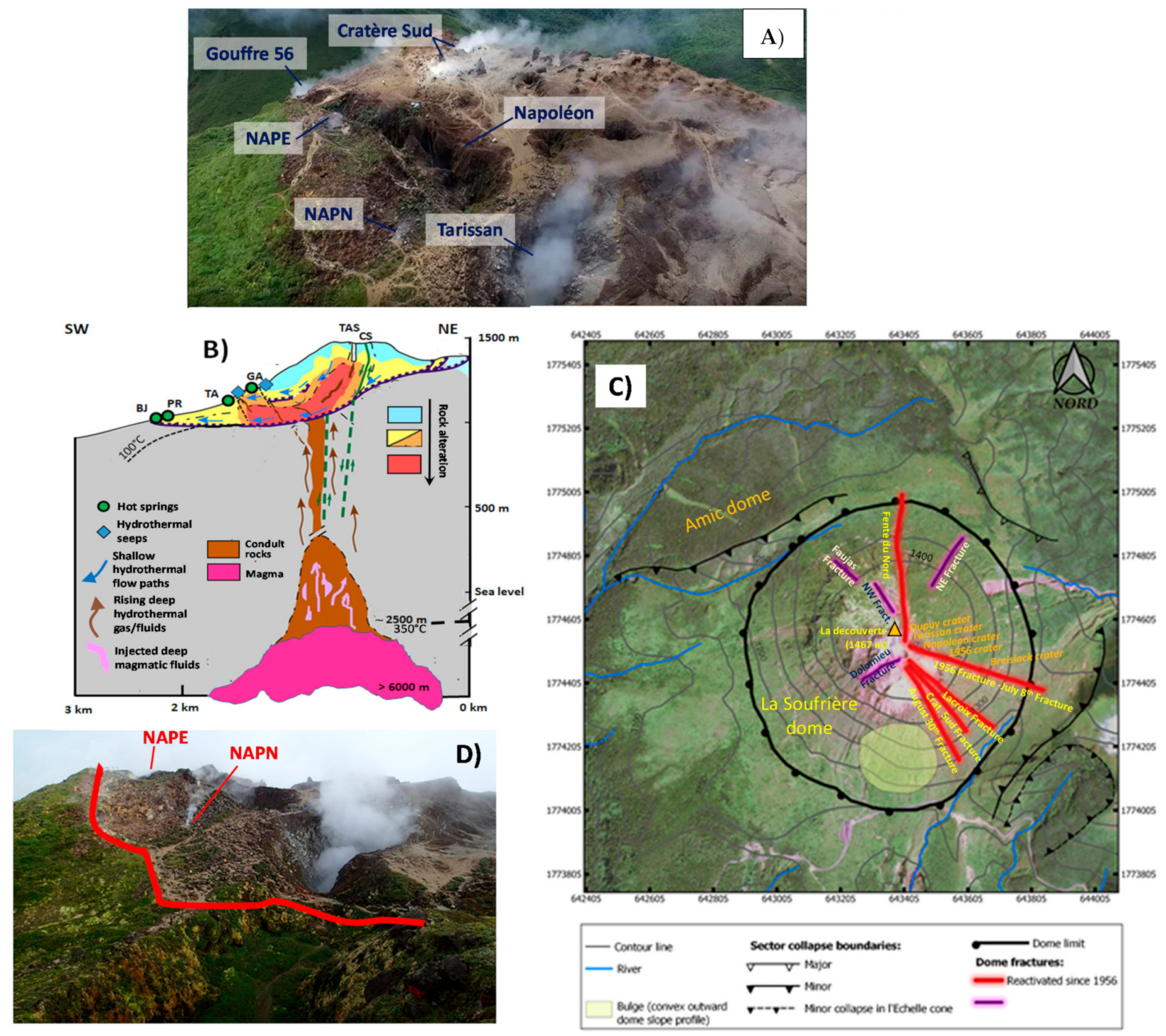

Figure 2. The Soufrière-Grand Découverte volcanic complex. (A) Drone view of La Soufrière dome summit with indication of main emission centres (courtesy of the OVSG-IPGP). (B) NE-SW geological profile of the main rock alteration profile and shallow plumbing system (modified from Rosas-Carbajal, 2016 [10]). (C) Simplified geological mapof La Soufrière dome and its surroundings (based on Microsoft ${ }^{\circledR}$ Bing $^{\mathrm{TM}}$ Maps and Brothelande et al. 2014 [11]). (D) View of La Soufrière dome illustrating the expanding hot and degassing area and with the NAPN (2014) and NAPE (2016) fumaroles.

The volcanic forms are, of course, responsible of the rapid evolution of landscape. The volcano-related hydrothermal activity and the consequent hydrogeology largely contribute to the high scenic value, making Guadeloupe very popular for geotourism. On one side, geotourism, a rapidly growing form of ecotourism, by vocation sustains and/or enhances the geographical character of its environment, culture, aesthetics, heritage, and the welfare of its residents (Turner, 2006, Lew, 2002; Buckley, 2003; and Kim et al. 2008 [12-15]). On the other side, geotourism, intended as geological tourism, is a type of tourism that comprehensively explores and somehow exploits the site geodiversity (Downling and Newsome, 2018 [16]) and represents a formidable opportunity for sustainable economic development. This is particularly true for volcanic-hydrothermal sites, where, however, the potential hazards facing tourists, as well as residents, must be recognized and mitigated. The recent hydrothermal eruptions at Ontake (64 casualties; Oikawa et al. 2016 [17]) and White Island (21 casualties; You Lim and Flaherty, 2020 [18]) volcanoes remind us how strategic is the short-term assessment of the hazards associated with phreatic explosions. 
Because of La Soufrière having unrest since decades ago and the presence of an extensive hydrothermal system (Moretti et al. 2020 [19], and references therein), a range of hazards are posed to tourists and residents. The bulk of potential volcanic hazards range from: (1) acid rain, (2) gas emissions, (3) earthquakes, (4) landslides, (5) falls (tephra and ash), and (6) flows (mud, lava, and pyroclastic). In strict connection with this, important threats are also related to the water resource, which can be naturally contaminated by enhanced volcanic-hydrothermal activity, as recently discussed during the 2019 and 2021 volcanic exercises conducted in the frame of the so-called Journées Japonaises (Préfet de la Région Guadeloupe, 2021 [20]).

In light of the resilience that volcanic islands must display, mid- and long-term strategies must be put in place in order to set an economic model around the sustainable exploitation of the resources related to the volcanic geodiversity, particularly hydrothermal ones, and, more generally, the groundwater resources. This paper is then an expanded review based on available data from published studies and reports, which aims at making the point about hydrothermal geodiversity of the Basse-Terre Island of Guadeloupe, particularly of La Soufrière andesitic volcano, and explore the challenges about the hydrothermal-volcanic resources and related risks. In particular, we target hydrothermal resources in the volcanic dome surroundings from the point of view of the preservation of the quali-quantitative state of deep volcanic groundwaters, which represent a strategic resource for future generations and as a source of energy. Besides, we stress its integration into a unique territorial observatory worthy of all monitoring, research, and development issues aimed at the analysis of natural risks undermining the conservation of the geo- and biodiversity.

By building on the volcanic-hydrothermal features making up a part of the well assessed Guadeloupe's geodiversity, this contribution also provides elements to civil and business participants and decision-makers to prospect the basic features of an integrated plan of resilient and sustainable development in which the resilience and the responsive actions demanded by sudden shocks like volcanic eruptions complement "low" transitions due to the most pressing global crises, that supersede the ongoing COVID-19 pandemic, such as global biodiversity loss and climate change. The recent eruption in nearby St. Vincent (Andrews, 2021 [21]), a SIDS located $350 \mathrm{~km}$ south of Guadeloupe, testifies for this necessity.

\section{Context and Geo-Volcanological Background}

\subsection{Geographical and Geological Setting of the Guadeloupe Island and Archipelago}

The Guadeloupe archipelago is situated in the Eastern Caribbean, comprising of mostly volcanic islands, formed by the subduction of the Atlantic Plate under the Caribbean Plate (Figure 1). This subduction process formed a number of volcanic islands, including the Basse-Terre island of the Guadeloupe archipelago, from the Virgin Islands in the north to the islands off the coast of Venezuela in the south.

Guadeloupe is one of the four overseas departments of France and administratively consists of six populated different islands (Basse-Terre, Grande-Terre, La Désirade, MarieGalante, Terre-de-Haut, and Terre-de-Bas, the last two being the two inhabited islands of Les Saintes archipelagi) plus the seven uninhabited islets of Les Saintes (L'îlet à Cabrit, Grand-Îlet, La Coche, Les Augustins, La Redonde, Le Pâté, and Les Roches percées) and the two uninhabited islands making up Petite-Terre. The Guadeloupe archipelago has a total surface area of $1628 \mathrm{~km}^{2}$ and a total population of 388,000 (Chanteur and Reif, 2020 [22]), giving a demographic density of 228 inhabitants $/ \mathrm{km}^{2}$. A natural marine channel, the Rivière Salée, separates the largest two islands of the archipelago, Basse-Terre $\left(848 \mathrm{~km}^{2}\right)$ and Grande-Terre $\left(590 \mathrm{~km}^{2}\right)$. Basse-Terre, the highest island of the Lesser Antilles with the active Soufrière of Guadeloupe volcano (1467 m a.s.l.), and Les Saintes archipel are mountainous islands formed entirely of tertiary and quaternary volcanic rocks. GrandeTerre, Marie-Galante, and Petite-Terre islands are composed of Pleistocene reef limestones overlying an older pre-Miocene volcanic substrate. La Desirade island is a tilted limestone 
elongated plateau of lower Pliocene age overlying Upper Jurassic or Lower Cretaceous igneous rocks, including pillow-lavasa (Bès de Berc et al. 2007 [4]) (Figure 1).

\subsection{The Basse-Terre Eruptive Centres}

In the Lesser Antilles, the most recent geological formations are active volcanoes at their highest altitudes and steepest slopes. In the proximity of these volcanic centres, carbonate sediments and limestone are absent. Basse-Terre island in Guadeloupe consists of seven main eruptive fields (from oldest to youngest): the Basal Complex, the Northern Chain, the Axial Chain, the Chaîne de Bouillante, the Monts des Caraibes, the Trois-RivièresMadeleine complex, and the active Grande Découverte- Soufrière (GDS) massif (Figure 1). They each contain many distinct eruptive centres that form a continuous $55 \mathrm{~km}$-long volcanic chain trending NNW, up to $25 \mathrm{~km}$ in width, and which reach a maximum elevation of $1467 \mathrm{~m}$ on top of the Soufrière dome. The latter formed during the last magmatic eruption dated at c. $1530 \mathrm{AD}$ (Boudon et al. 2008 [23]). Volcanism in Basse-Terre started about 3 Ma ago (Samper et al. 2009 [24]) with the construction of the Basal Complex and then of the Northern Chain to the North of Basse-Terre. Age determinations by Blanc (1983) [25], Carlut et al. (2000) [26], and Carlut and Quidelleur (2000) [27] have constrained the timing of volcanism on Basse-Terre during the last million years. The Axial Chain formed south of the Northern Chain between $1 \mathrm{Ma}$ and $0.445 \mathrm{Ma}$, in part contemporaneously with the onset of volcanism of the Bouillante Chain. Between about 0.6 Ma and 0.25 Ma three volcanic complexes were active in southern Basse-Terre; the Axial Chain, the Chaine de Bouillante, and the Monts Caraibes. Activity at the Grande-Découverte Soufrière volcanic complex began around 0.2 Ma or even earlier (Blanc et al. 1983 [25]; and Samper et al. 2009 [24]) and is still continuing at present. Although precise chronological constraints are still missing, current stratigraphical constraints indicate that the Madeleine Trois-Rivières volcanic complex is the most recent complex to have begun its activity in southern BasseTerre, after the onset of the Grande Découverte-Soufrière complex and probably within the last 0.1 Ma (Samper et al. 2009 [24]).

\subsection{La Soufrière Volcano and the Ongoing Unrest}

La Soufrière is the most recent building of the GDS volcanic complex, made up of three composite volcanoes, Grande Découverte, Carmichael, and Soufrière, built 0.445 million years ago on the southern flanks of the ancient composite volcano of Sans Toucher (about $0.5 \mathrm{Ma}$ old) (Carlut et al. 2000; and Samper et al. 2007 [26,28]). La Soufrière eruptive history began around 9150 years ago (Legendre, 2012 [29]). It is an active volcano, of the explosive type, which has experienced numerous magmatic and non-magmatic eruptions, the latter known as "phreatic". At least four major Plinian eruptions, which may form a caldera, have occurred in the GDS complex, the most recent event being around $0.042 \mathrm{Ma}$. At least 15 Holocene magmatic eruptions (9 lava dome eruptions and 6 Subplinian to Plinian explosive eruptions) have been identified (Legendre, 2012 [29]). The most recent major multi-phase magmatic eruption in $1530 \mathrm{AD}$ began with the collapse of the edifice causing a landslide that reached the sea at Basse-Terre. The explosive eruption (sub-Plinian) which followed generated fallout of ash and pumice on the south Basse-Terre, the effusion of pyroclastic flows (incandescent avalanches of gas, ash, and blocks of rock) which reached 5-7 km distance from the volcano, and mudslides. It ended with the formation of the Soufrière dome (approximately 50 million $\mathrm{m}^{3}$ ) (Komorowski, 2005; Figure 2 [30]). La Soufrière is characterized by an exceptional rate of at least nine collapses over the past 9150 years that have introduced debris-avalanches, mainly in the south-west sector, over distances of 9 to $15 \mathrm{~km}$ (Legendre, 2012; and Peruzzetto et al. 2019 [29,31]).

Recent studies have shown that a small magmatic eruption may have occurred in 1657 ( \pm 20 years) (Legendre, 2012 [29]). However, the historical activity of La Soufrière is characterized by non-magmatic eruptions, which were minor in 1690,1812, and 1956, and major in 1797-1798, 1836-1837, and 1976-1977. The 1956 phreatic eruption lasted 10 days with two surface explosions (Figure 3). That of 1976-1977 was particularly violent with 
26 major explosions between July 1976 and March 1977. It produced emanations of acid gases, vertical and laterally directed projections of blocks and ash, small cold pyroclastic flows of low volume, mudslides, and about 16,000 earthquakes, of which 150 were felt, including the magnitude $\mathrm{M}_{\mathrm{L}} 4.2$ earthquake on 16 August 1976 (Dorel and Feuillard, 1980; and Feuillard et al. 1983 [32,33]). It was a phreatic or hydrothermal eruption, or even an aborted magmatic eruption according to another hypothesis, in which the magma did not rise to the surface.

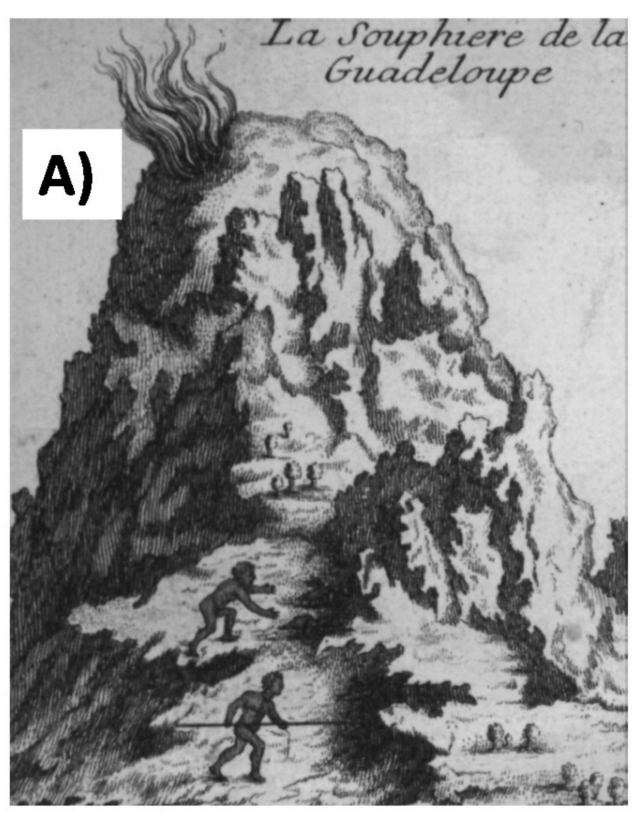

1797-1798

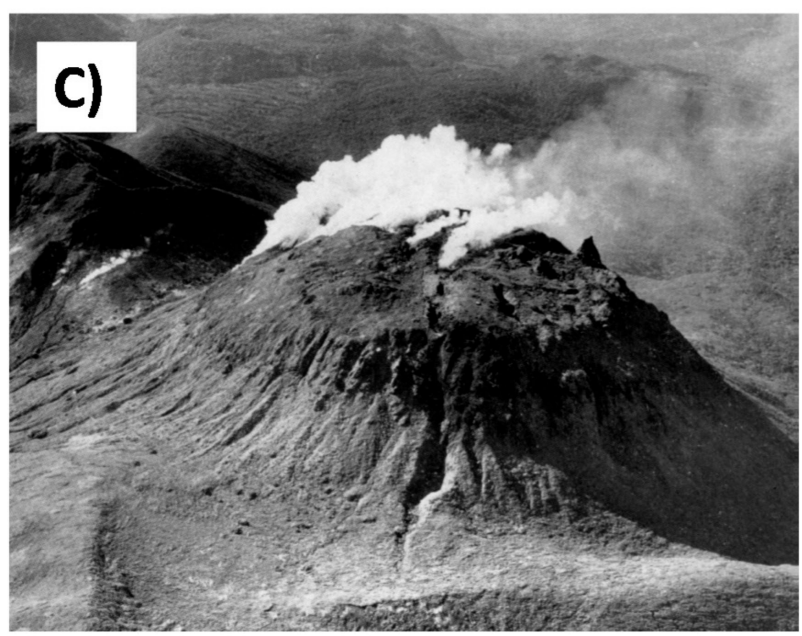

1956

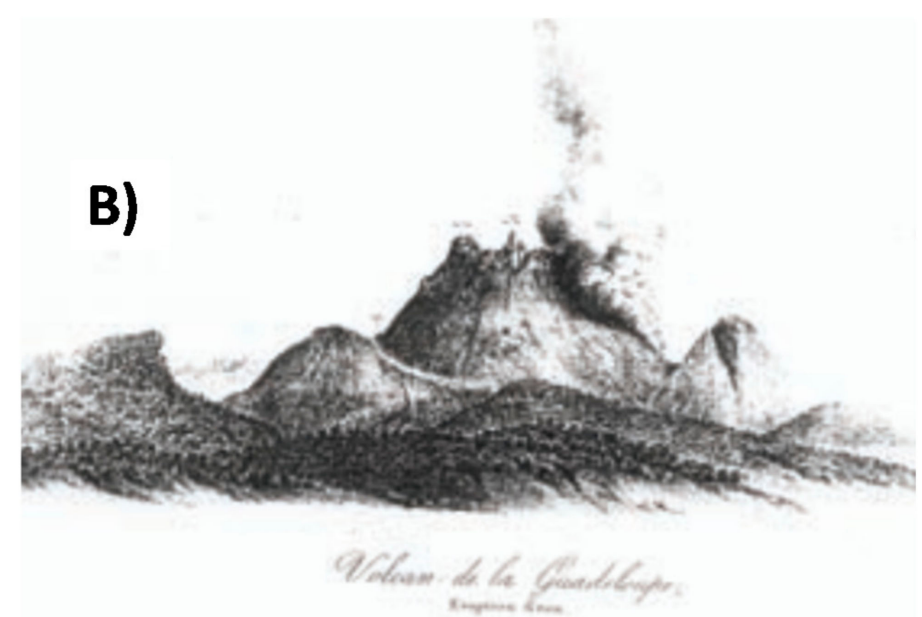

1836-1837

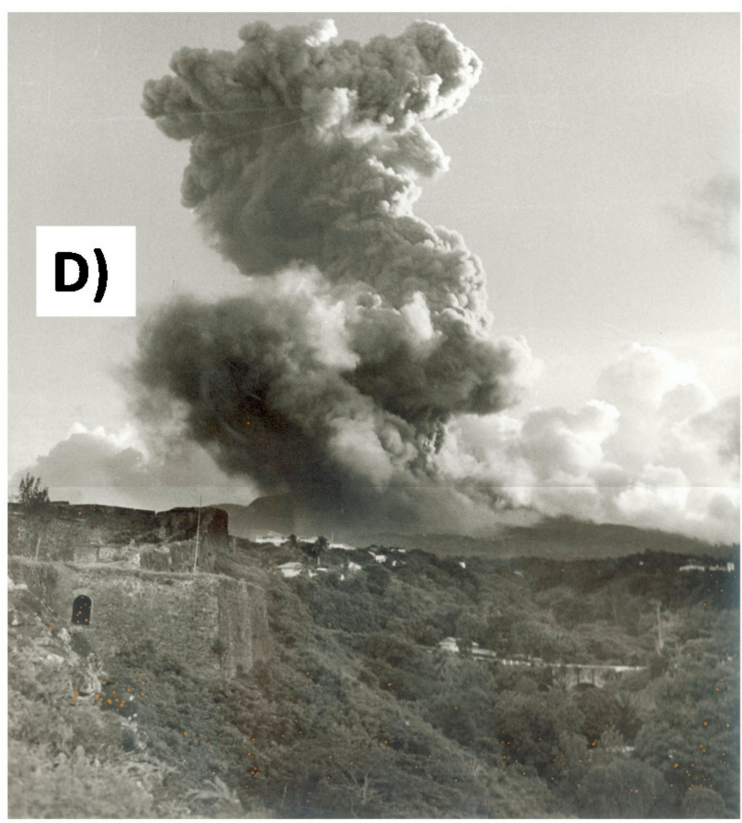

1976-1977

Figure 3. Images of historic phreatic eruptions; based on pictures (A-D) from Labat (1732), Biot et al. (1837), Barabé and Jolivet (1958), and M. Feuillard (OVSG-IPGP database). See also Komorowski et al. (2005) [30,34-36].

The 1976-1977 volcanic crisis led to the evacuation of about 70,000 people and serious socio-economic consequences for the island (e.g., Feuillard et al. 1983; Hincks et al. 2014; and Komorowski et al. 2015; Figure $3[33,37,38])$. The materials ejected during the explosive hydrothermal eruption of 1976-1977 were largely hydrothermally altered (e.g., Feuillard et al. 1983 [33]), highlighting the link between the hydrothermal system and volcanic activity. Geological studies have also shown that La Soufrière de Guade- 
loupe has experienced an exceptional record of partial edifice collapse (at least eight in the past 9150 years) that have produced extensive debris avalanche deposits composed of hydrothermally altered materials (Komorowski et al. 2005; Le Friant et al. 2006; Salaün et al. 2011; Rosas-Carbajal et al. 2016; Peruzzetto et al. 2019; and Heap et al. $2021[10,30,31,39-41])$.

After the 1976-1977 crisis, the volcano remained in a state of repose notwithstanding low levels of fumarolic activity at the SW base of the dome, along the Ty fault (Zlotnicki et al. 1992; Allard et al. 1998; Komorowski et al. 2005; and Villemant et al. 2005 [30,42-44]) until 1992. Then, degassing renewed on top of the lava dome, alongside the reactivation of thermal springs that have remained dry since 1977 and the appearance of new ones at the southern base of the dome (Villemant et al. 2005, 2014 [44,45]). The concomitant revival of the shallow seismicity confirmed a reactivation of the hydrothermal system activity, with circulations of gas, steam, and water under pressure in the porous and fractured rock (Brombach et al. 2000; Allard et al. 2014; Villemant et al. 2004; Rosas-Carbajal et al. 2016; OVSG-IPGP, 1999-2021; and Moretti et al. 2020 [10,19,45-48]).

Fumarolic degassing, initially concentrated at the Cratère Sud (hereafter CS, Figure 2), extended then along the Napoleon fracture (1997), the Tarissan crater lake (1998), the Gouffre 56 (2007), the Lacroix fracture (late 2011), and eastward in the proximity of the Breislack crater (2013; Figure 2), along the fracture that was involved in four of the six historical non-magmatic explosive eruptions of La Soufrière (Komorowski et al. 2005 [30]; and Rosas-Carbajal et al. 2016 [10]). The degassing area continued to expand on top of the lava dome, with the appearance of a new fumarole (Napoleon Nord, hereafter NAPN; Figure 2 in July 2014, and of Napoleon Est (NAPE; Figure 2 that opened further east between 8 and 10 February 2016 with a very small steam blast (in the sense of Mastin, 1995 [49]) with hot mud projections over a distance of 5-10 m radius.

Presently, all these vents are active and degassing low-temperature fumaroles (around $100{ }^{\circ} \mathrm{C}$ ). As recently as February-April 2018, concern was raised by an episode of accelerating unrest, when seismic activity peaked at the same levels as during the 1976-1977 phreatic crisis and yielded a $M_{1} 4$ earthquake. Such an accelerated episode was related to the arrival of deep hot magmatic gas, which affected the hydrothermal system and triggered seismic activity in the dome and its surroundings, in parallel with the reactivation of pre-existing tectonic fractures by hydroshearing and/or hydrofracturing (Moretti et al. 2020 [19]).

The main features of the ongoing unrest are given by (1) the continuous expansion of the degassing area on top of the lava dome and (2) with the appearance of new fumaroles in July 2014 and February 2016. The expansion was accompanied by an increase of thermal ground release (increased from 1.2 MW to $8 \mathrm{MW}$ ), that escalated the heat output due to fumarolic steam release, that notably has been roughly constant from 2010 to 2020 (28 MW; Jessop et al. 2021 [50]). Fumarolic emissions are steam dominated and characterized by a deep magmatic gas component (Brombach et al. 2000; Villemant et al. 2014; and Moretti et al. 2020 [19,45,46]). Warm sulphate-chloride springs with relatively high flowrate are observed on the slopes and at the base of the dome and are associated with the underneath degassing magmatic-body that supplies hot acid fluids, $\mathrm{CO}_{2}, \mathrm{SO}_{2}, \mathrm{H}_{2} \mathrm{~S}, \mathrm{HCl}$, and HF, to the above hydrothermal system (Villemant et al. 2005, 2014 [44,45]). The resulting acid fluids are (a) partly rapidly transferred through the highly permeable and high-flow dome structures feeding the steam-rich summit fumaroles and (b) partly are involved in the circulation through rocks with argillic alteration (Brombach et al. 2000; Villemant et al. 2014; Moretti et al. 2020; and Sanjuan et al. $2011[19,45,46,51])$.

The hydrothermal dynamics produces pore pressure increase and inflation that represent the first-order term of the observed shallow deformation (Moretti et al. 2020 [19]). Because of the same dynamics, seismic activity is mainly concentrated in the volcanic edifice at depths at or above sea level, with magnitudes $\mathrm{M}_{1}<1$ (OVSG-IPGP bulletins available online: http:/ / www.ipgp.fr/fr/ovsg/bulletins-mensuels-de-lovsg, accessed on 30 September 2021; Moretti et al. 2020 [19]). 
Increase in hydrothermal activity and low-energy shallow seismicity has prompted a significant upgrade in (1) the monitoring capacity and surveillance networks of the OVSG (IPGP), and (2) the mitigation and emergency planning by civil protection authorities and public awareness campaigns (that include a monthly public activity bulletin disseminated online since 1999). Access to the entire summit was closed by the Prefect and the National Park in August 1999, however, in 2001 a revised delimitation of parts of the summit area that are subjected to the acid plume was officially closed off to the public. In 2019, the Préfecture de Guadeloupe, with the decree n²019/001 CAB SIDPC of 14 January 2019, instituted regulated access to the top of the Soufrière volcano, based on the identification of a security perimeter and the prohibition of any unauthorized person crossing it. Tourist access is possible if accompanied by authorized guides.

Currently (as of this publication), there are no instrumentally recorded signs that magma is rising or located near the surface. Nevertheless, because of the slow systematic increase in the seismic, fumarolic, and thermal activity of the volcano, and the fact that minor historical phreatic eruptions $(1836$; 1956) were not preceded by major noticeable changes, La Soufrière remains in a state of scientific and instrumental vigilance at alert level two ("Increasing activity") over four. This level was confirmed also after the accelerated unrest episode of February-May 2018, which was interpreted as a failed phreatic eruption (Moretti et al. 2020 [19]).

\section{An Overview of the Water Resource in the Volcanic Context of the Basse-Terre Island}

When the Amerindian Arawak tribe settled in Basse-Terre (300 CE) they named the newfound territory Karukera, meaning the island of beautiful waters (https:/ / www. culture.gouv.fr/Regions/Dac-Guadeloupe/La-DAC/La-Guadeloupe-en-bref, accessed on 30 September 2021). Indeed, the Basse-Terre displays a variety of inland waters, including rivers, lakes, springs as well as thermal springs and fumarolic-related steam emissions fed by the Soufrière hydrothermal system. All these water resources contribute greatly to the bio- and also geo-diversity of Basse-Terre. With its volcanic peaks, the Basse-Terre is considered the water tower of Guadeloupe, being drained by more than 47 rivers. These represent the main source of fresh water in Guadeloupe and a great part of the $91 \%$ (77\% from rivers; and $14 \%$ from spring waters) of the withdrawn volume $\left(80.6 \mathrm{~mm}^{3}\right)$ that is currently provided for the drinking water supply (DWS) (Office de l'Eau 971, 2020 [52]).

In addition to the rivers, another source of fresh water in Basse-Terre is the groundwaters, to which the hydrothermal system of La Soufrière contributes at different degrees in many sectors, mainly within the Mt. Amic caldera rim and the southern coastline (e.g., Villemant et al. 2014; and Raguenel et al. 2019 [45,53]; Figures 1 and 2). Therefore, both shallow and deep groundwaters record at different degrees the effects due to climate-change and volcanic activity. The feedback from these two forces must be carefully assessed and considered for future initiatives on biodiversity and geodiversity.

\subsection{Climate-Related Drivers}

The climate of Guadeloupe is denoted as tropical maritime, with temperatures that are strongly dependent on the sea surface. It is hot all year round with temperatures above $18^{\circ} \mathrm{C}$, and characterised by heavy rainfall due to the frequent passage of masses of humid maritime air (Chaperon et al. 1983 [54]).

Guadeloupe's climate has two main seasons: the dry season (so called carême) runs from December to April with low temperatures and low relative humidity. The rainy season (or wet season) goes from June to November with high temperatures and relative humidity. Humid air masses play as an important role as solar radiation in diurnal variations. Humidity varies significantly during a day or a season and it is a difficult parameter to measure over the long term. Humidity is generally higher on the heights or upwind of a mountain and lower in the plains. Basse-Terre island has a mean annual temperature of around $23{ }^{\circ} \mathrm{C}$ and $75 \%$ humidity (Dessert et al. 2015 [55]). The Piton de Sanner weather station of the Observatoire Volcanologique et Sismologique de Guadeloupe (OVSG), located on La 
Soufrière summit, records an average humidity of 98.5\% (OVSG-IPGP unpublished data). A morphological obstacle like the Soufrière massif causes orographic rain because of the Fhoen effect (Allemand et al. 2014 [56]) on air saturated masses transported by eastern trade winds. Due to Basse-Terre's volcanic relief, the Eastern coast (windward) of Guadeloupe receives more rain than the Western coast (leeward). Additionally, rainfall can be facilitated by the presence of microparticles due to the Saharan dust carried by trade winds, which mix with local fumarolic emissions and plumes due to the volcanic-hydrothermal activity. Therefore, rainwater analyzed in Guadeloupe, as well as in other Caribbean islands, may contain traces of Sahara dust with sea salt (Dessert et al. 2015 [55]).

Figure 4 shows average rainfalls in Base Terre island, a wetland on the windward coast of Basse-Terre, with 1600 to $3500 \mathrm{~mm}$ and, finally, a very wet zone with between 3500 and up to 10,000 $\mathrm{mm}$ per year above $600 \mathrm{~m}$ altitude including the summit of La Soufrière (Chaperon et al. 1983; Plaisir et al. 2003; and Dessert et al. 2015 [54,55,57]). Up to 30\% of the rainfall infiltrates the soil to reach groundwaters (Rad et al. 2007 [58]). The river runoff is, however, very variable, ranging from $1000 \mathrm{~mm}$ /year to $5000 \mathrm{~mm}$ /year, depending on season, altitude, and geographical location in the drainage basin (Gaillardet et al. 2011 [59]). Due to the sharp relief, river basins are small (between 3 and $20 \mathrm{~km}^{2}$ ) and rivers have generally a torrential regime. The water transfer times to the sea are short, i.e., less than a few hours.

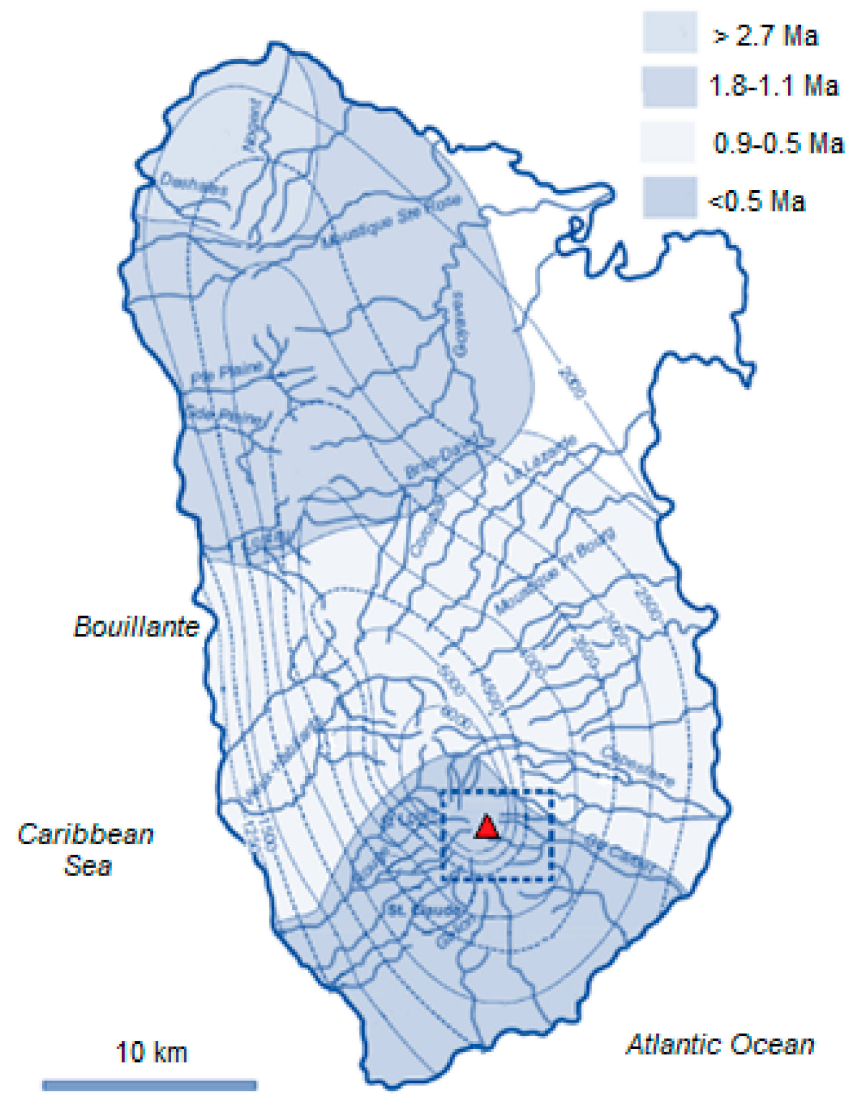

Figure 4. The average spatial distribution of cumulative rainfall in Basse-Terre and its overlap to the river network and different colored fields referring to north-south gradient of the ages of geological formations. The red triangle shows the Soufrière summit. Modified from Dessert et al. (2015) [55].

The precipitation from one year to the next is strongly impacted by the passage of cyclones, which can produce in one or two days the rainfall equivalent of one to two months: for example, in September 2017 the OVSG rain gauge in Savane à Mulets (1142 m on the Sufrière southern flank) recorded $440 \mathrm{~mm}$ of rainfall in $24 \mathrm{~h}$ during the passage of the 
hurricane Maria (http:/ /volcano.ipgp.fr/guadeloupe/Bulletins/2017/OVSG_2017-09.pdf, accessed on 30 September 2021; Saurel et al. 2021 [60]).

\subsection{Groundwaters and Geothermal Systems}

Groundwaters from Basse-Terre are used for drinking water supply from spring catchments. There is also exploitation by drilling and water collecting from sources for the production of bottled water, mainly in the south of the island (factories in Capès and Matouba). The underground resource in the Bouillante sector is exploited by deep drilling (between 800 and $2500 \mathrm{~m}$ ) for the production of geothermal energy.

Terrestrial and underwater hydrothermal vents are numerous in Guadeloupe due to volcanic activity and the nature of the altered and fractured massif. Inland thermal manifestations are concentrated mainly on and around La Soufrière dome (Figure 2) and in the Bouillante geothermal area (Figure 5). Two thermal springs are known in the northern part of the island (Sainte-Rose and Lamentin) and two south of La Soufrière, in Gourbeyre (Figure 5).

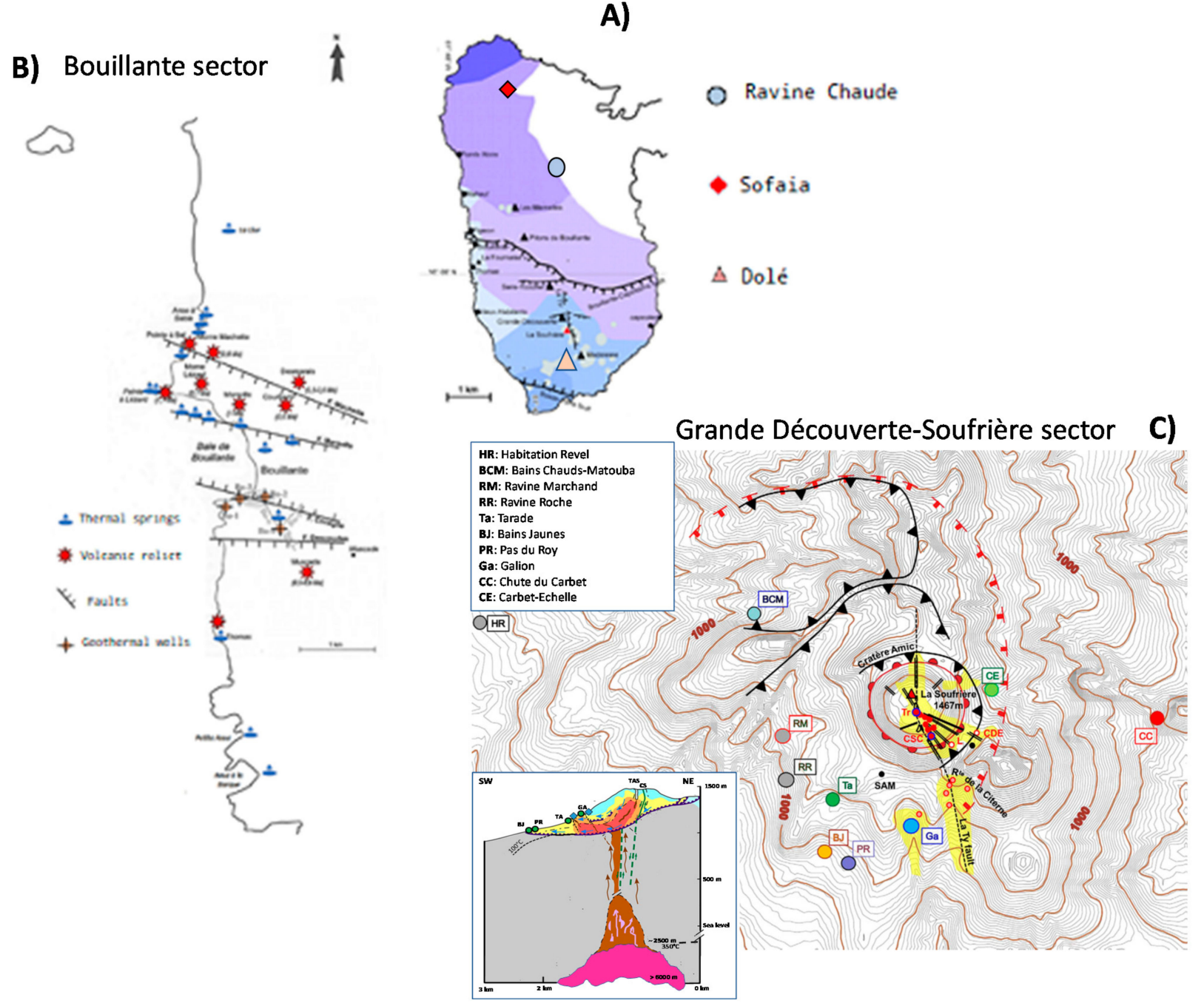

Figure 5. (A) Simplified geological map showing site location of Sofaia, Ravine Chaude et Dolé hot springs inland BasseTerre (modified from Thinon et al. 2010 [61]). (B) Zoom on the west (downwind) coast, and the Bouillante sector (modified from Bouchot et al. 2009 [62]). (C) Hot springs located within La Soufrière Grande Decouverte complex (modified after Villemant et al. 2014 [45]).

The porous nature of rocks and the network of W-E and N-S faults (Feuillet et al. 2002 [9]; Figure 1) favours infiltration of water, which is estimated to be on average $30 \%$ 
of the annual rainfall (Rad et al. 2007 [58]). Nevertheless, the hydrogeological functioning of the island of Basse-Terre is poorly understood due to the great complexity of the geological structures that further compounds the associated risks to the groundwater resource. This is particularly evident in the poor quality of wastewater treatment as well as volcanic-hydrothermal-activity that accompanies La Soufrière unrest that threaten acquifers, particularly deep ones, which represent a strategic stock for the whole island.

The large distance $(15 \mathrm{~km})$ between La Soufrière and the Bouillante geothermal system, and the location of Bouillante in the older, extinct volcanic areas, has fed discussions about a second, hidden magmatic heat source below the Bouillante system that is not associated with volcanic features and does not follow the north-south age trend (Calcagno et al. 2012 [63]; see Figure 1). Figure 6 shows a typical profile for a hydrothermal system associated with andesitic arc volcanism, which could potentially be represent La Soufriere's. The profile is extended west-ward (Figure 6A) to take into account the Bouillante area, which based on magneto-telluric (MT) soundings (Figure 6B) is not related to large-scale heat transfer from La Soufrière to Bouillante but requires a second magma chamber, that lacks at surface volcanic manifestations, beneath the Bouillante geothermal system and high-permeability vertical conduits transferring hot fluids circulating at depth (Figure 6B; Raguenel et al. 2019 [53]).
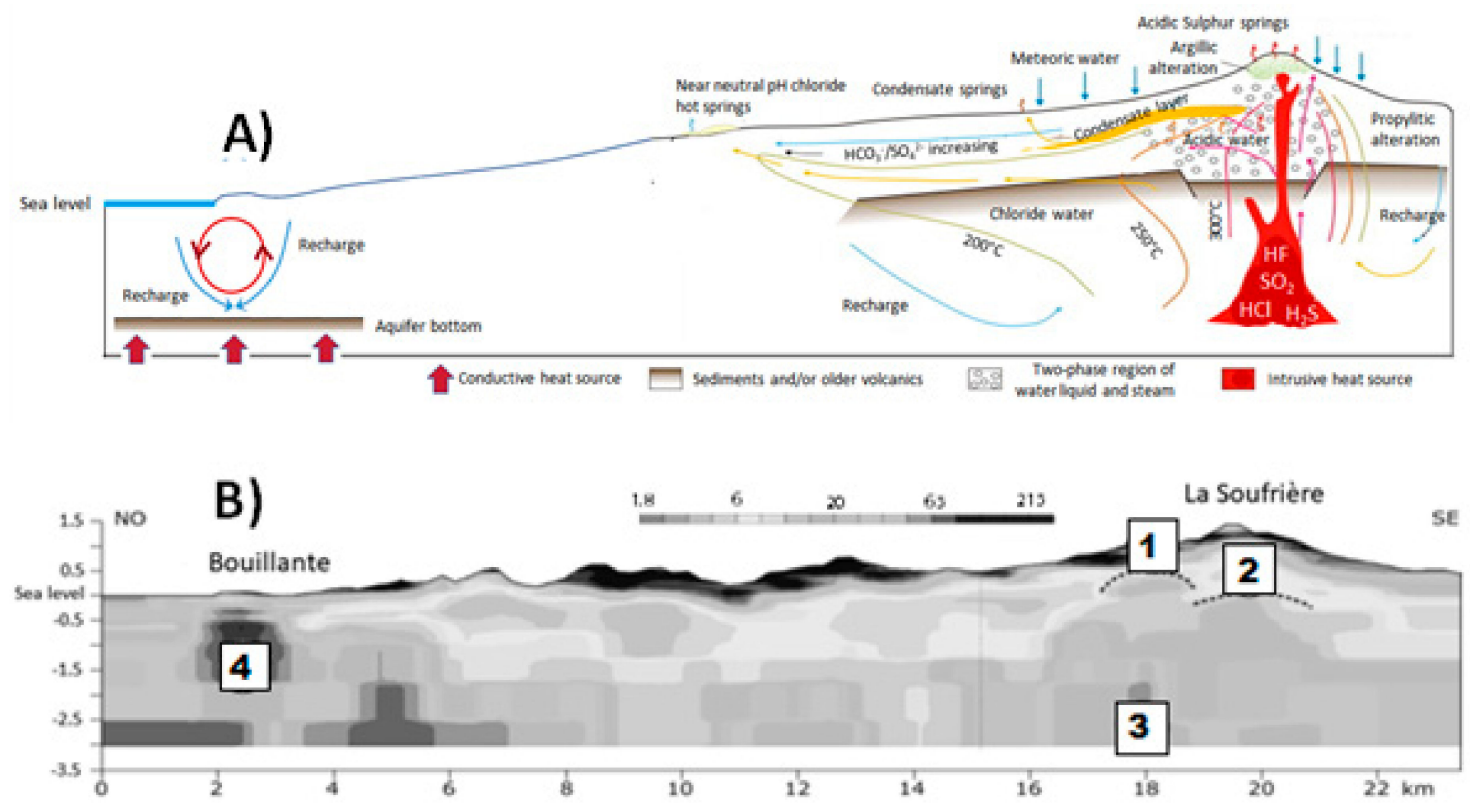

Figure 6. (A) Geothermal sketch related to an active volcanic field typical for an island arc setting above a subduction zone and approximating the Soufrière-Bouillante sectors of Basse-Terre in Guadeloupe (modified from Moeck, 2014 [64]). (B) Magneto-telluric (MT) cross-section along La Soufrière et Bouillante sectors showing a well-defined dome-shaped horizon with conductive properties (1), a deep upflow likely rising from La Soufrière magma chamber (2), a deep resistive zone in the Soufrière roots (3), which could correspond to a potential heat reservoir, and a well-resolved resistive unit associated with the Bouillante reservoir (4) (modified from Raguenel et al. 2019 [53]). The MT section of (B) can thus be interpreted in line with the schematic representation in (A).

Thermal waters are mostly meteoric in origin, however, some exhibit a magmatic signature that becomes important for fumarolic steam waters (Jeremie and Pascarelli, 1992; Brombach et al. 2000; and Villemant et al. 2014 [45,46,65]). Tritium isotope data of thermal waters reveal that they all have an age $<20$ years, with many showing a seasonal variability of ${ }^{18} \mathrm{O}$, pointing to transfer times $<1$ year (Jeremie and Pascarelli, 1992 [65]).

The Basse-Terre thermal waters can be divided into the following five hydrochemical types, on the basis of relative $\mathrm{Na}^{+}, \mathrm{Ca}^{2+}$, and $\mathrm{Mg}^{2+}$ contents and relative $\mathrm{Cl}^{-}, \mathrm{SO}_{4}{ }^{2-}$, and $\mathrm{HCO}_{3}{ }^{-}$concentrations (Figure 7): (a) $\mathrm{Na}-\mathrm{Cl}$, (b) $\mathrm{Na}-\mathrm{HCO}_{3}$, (c) $\mathrm{Ca}-\mathrm{SO}_{4}$ (transitioning to Ca$\mathrm{SO}_{4}-\mathrm{Cl}$ waters) to (d) $\mathrm{Ca}-\mathrm{Na}-\mathrm{Cl}$, and (e) $\mathrm{Ca}-\mathrm{Na}-\mathrm{HCO}_{3}$ waters. All of them are represented 
and span over a large temperature range $\left(30^{\circ} \mathrm{C}\right.$ to $>90{ }^{\circ} \mathrm{C}$, the latter occurring underwater offshore of Bouillante). Their compositions reflect the interaction of the volcanic rock with hot water (more likely affected by mixing with volcanic gases that bring acid gases $\left(\mathrm{CO}_{2}\right.$, halogens, and sulphur species) into groundwaters) (e.g., Ruzié et al. 2013 [66]) and give rise to a plethora of neutralization, redox, and disproportionation reactions in which the surrounding rock is lixiviated. Where the contribution of volcanic gas is absent, heat supplied by conduction supports water-rock alteration driven by $\mathrm{CO}_{2}$ gradients of biogenic origin, which in the highly-vegetated tropical environment is abundant and give rise to a top-down fluid-rock interaction that additionally at many sites contributes to the bottom-up fluid-rock interaction caused by hydrothermal alteration (Rivé et al. 2013 [67]). Hydrogeochemical standard methods adopted are described in referenced articles which follow in this section. These include the collection of raw, filtered $(0.45 \mathrm{~mm})$, and filtered-acidified (with nitric acid, $\mathrm{HNO}_{3}$ ) aliquots of water in polyethylene bottles for the determination of chemical constituents by using ion chromatography for major ions in Figure 7, spectrophotometry for dissolved silica and Inductively Coupled Plasma Mass Spectrometry (ICP-MS) for trace elements. Besides, filtered aliquots can also be stored in glass bottles for eventual isotope analyses by Isotope-Ratio Mass Spectrometry (IRMS) and/or Cavity Ring-Down Spectroscopy (CRDS) based using the near-infrared absorption spectrum. Outlet temperature, $\mathrm{pH}$, alkalinity (by titration with $\mathrm{HCl} 0.1 \mathrm{~N}$ using methylorange as indicator), and electric conductivity are typically measured in the field.
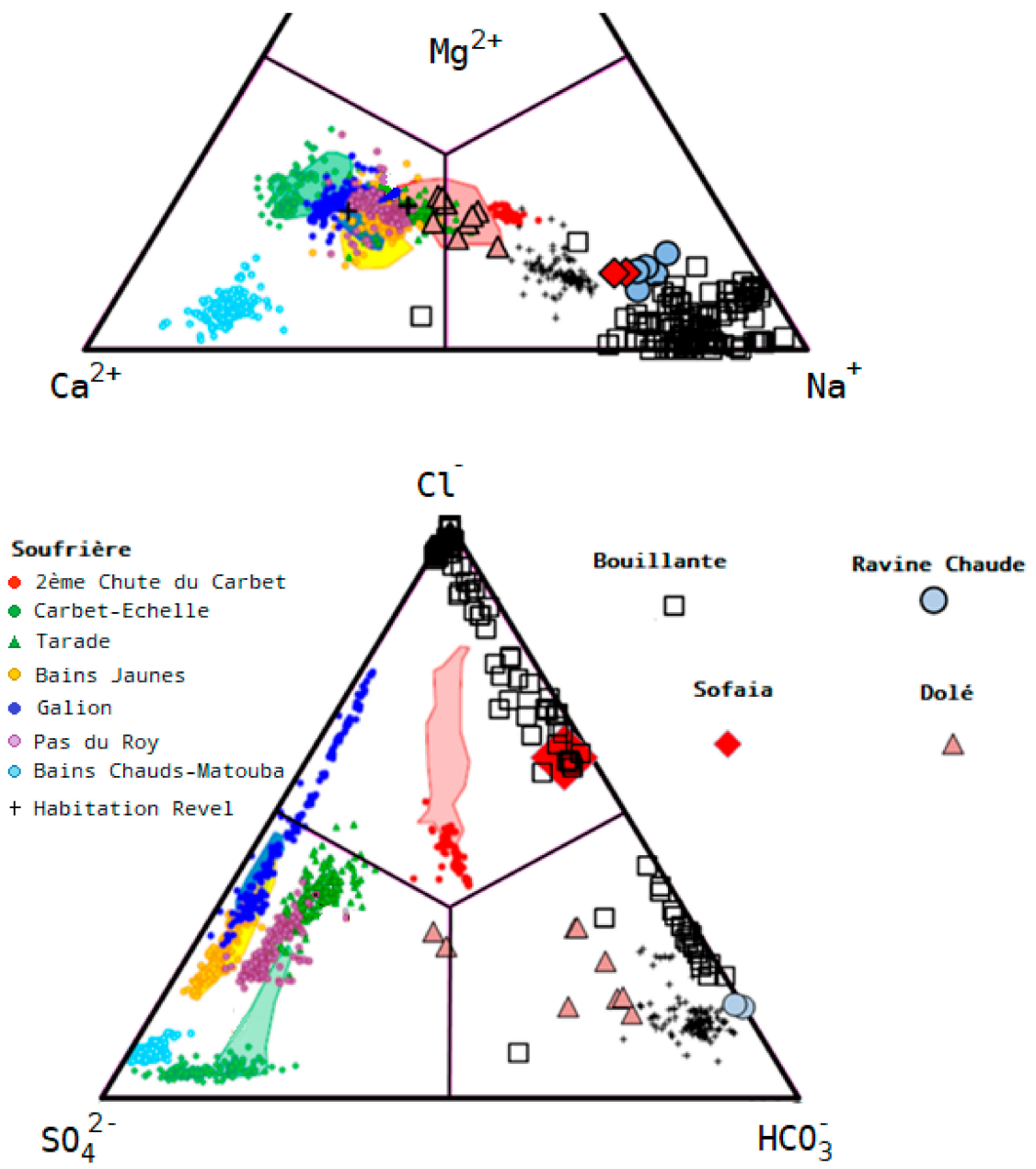

Figure 7. Triangular diagrams reporting the cationic and anionic chemistry of hot springs in the different sectors of the Basse-Terre Island, Guadeloupe. Modified from Villemant et al. 2014 [45], with addition of data for Bouillante, Ravine Chaude, Sofaia, Dolé from Bourdon et al. (2008) [68]. 


\subsubsection{The Bouillante Geothermal Field}

The geothermal system of the Bouillante sector (Figure 5) is well distinct from that of Soufrière and is located on the west coast of Basse-Terre Island, half-way between the north and south ends of the island (Figure 5). Low-pressure steaming ground occurs at Bouillante. In the 1970s four geothermal wells were drilled to depths of 350-2500 m during the exploration phase of the Bouillante geothermal field. With a reservoir temperature of about $260^{\circ} \mathrm{C}$, no vapor in the aquifer and an enthalpy of about $1100 \mathrm{~kJ} / \mathrm{kg}$, the Bouillante geothermal field is, in fact, a high-energy, high-temperature, medium-to-low enthalpy geothermal field (Lachassagne et al. 2009 [69]).

This area has been long known for its terrestrial hydrothermal surface expressions (hot springs, mud pools, steaming grounds, and fumaroles) and, consequently, the village has been named 'Fontaine Bouillante', and then Bouillante, which means 'boiling' in French. Early mentions of thermal waters of this sector can be found in 1647 by reverend fathers Breton and Armand, and then in 1742 by the Reverend Father Labat (Jeremie and Pascarelli, 1992 [65]). The springs were quickly identified and used for their thermal property from the first years of French colonization. However, hydrotherapy has not been developed in Bouillante.

Several thermal springs have been identified by the Bureau de Recherches Géologoqiues et Minéraires (BRGM) in the Bouillante sector and, particularly, around Bouillante Bay (Traineau et al. 1997 [70]), many of which are marine and located mostly in the north of Bouillante Bay (Sanjuan and Brach 1997; Sanjuan 2001; Sanjuan et al. 2001; and Sanjuan et al. 2004 [71-74]) (Figure 5). Hot springs of the Bouillante area are artesian and related to a double network of faults and fractures within andesitic rocks (Lachassagne et al. 2009 [69]).

Most of the springs are located on the coastline or underwater at sea in the Bouillante bay (sub-groups of Pointe de Lézard et Marsollen, where temperatures higher than $90{ }^{\circ} \mathrm{C}$ are reached at $23 \mathrm{~m}$ under sea Traineau et al. 1997, 2015 [75]; Figure 5). Temperatures vary from $30^{\circ} \mathrm{C}$ to $100{ }^{\circ} \mathrm{C}$ (Bourdon et al. 2008 [68]), but some of the springs recognised prior to 1985 and which were located in the Bouillante village (the presence of hot springs, fumaroles, and hot floors were numerous in the southern part of the village, from the cemetery to the stadium site) have disappeared, probably due to the exploitation of the geothermal system and growing urbanization, particularly road construction. These were most related to resurgence of phreatic groundwaters in which meteoric and seawater mix, further contaminated and heated by the deep rising geothermal fluids (Sanjuan et al. 2001 [73]). This is, for example, the case of the current hottest inland thermal springs of Bouillante, located in the cave of the drilling hole Bo-2 $\left(>90^{\circ} \mathrm{C}\right.$; see Figure 5) or in the very same area of the so-called source Tuyau, which discharges directly in a road drainage channel with an outlet temperature around $75^{\circ} \mathrm{C}$.

Accessible thermal springs are known both south (a-c below) and north (d, e below) of Bouillante in (Figure 5):

(a) Anse Thomas, where it is possible to bathe in a small basin on the coastline, in which thermal water $\sim 70{ }^{\circ} \mathrm{C}$ at and sea water mix resulting in a $\sim 10 \mathrm{~m}^{2}$ pool by the sea at $\sim 50^{\circ} \mathrm{C}$ (Figure 8 );

(b) Monchy, on the beach of Petite Anse, where hot water emerges from directly under the sand at the edge of the cliff. The spring can no more be sampled after the 1995 hurricane, but its temperature was between $40^{\circ} \mathrm{C}$ and $50^{\circ} \mathrm{C}$;

(c) Anse à la Barque, which is here included in the Bouillante sector (see also Brombach et al. 2000 [46]) but that some ascribe to the Sans Toucher/Vieux Habitants hydrothemal system via an E-W fault (Bourdon et al. 2008 [68]). Thermal waters are located below the lava flows surrounding the bay and diffuse in the sand by the sea at an average temperatures of $40^{\circ} \mathrm{C}$ (Bourdon et al. 2008 [68]). Other water resurgences are located in the nearby mangroves. Water composition result from mixing low-mineral and sea water at variable proportions;

(d) Bain du Curé (close to the Anse à sable beach), partially equipped since the 1950s with a $\sim 2 \mathrm{~m}^{2}$ concrete pool and having a temperature around $40^{\circ} \mathrm{C}$. Hot water comes 
directly into the rock of the coastal cliff. In order to increase the spring flow-rate, the rock was dynamited causing the opposite effect, the reduction in flow-rate. In the area other sources are at sea around the Pigeon Island; and

(e) La Lise, in the Bois-Malher valley, which is a completely abandoned site, in which the hot $\left(>40^{\circ} \mathrm{C}\right)$ water comes out on the ground over the entire area and is collected in three basins about $1 \mathrm{~m}$ deep and $4 \mathrm{~m}^{2}$ wide each. The waters are naturally filtered from the ground with sand at the bottom of the pools.
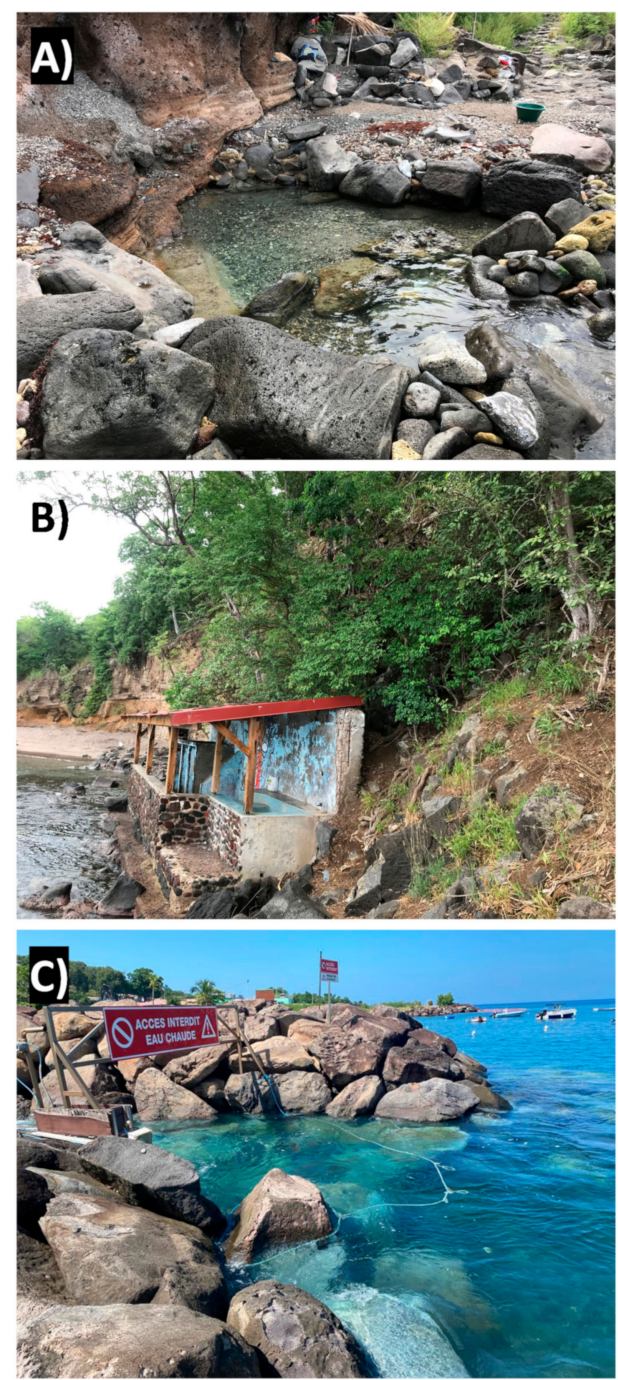

Figure 8. Images of selected hot springs and hot water effluents in the Bouillante sector. (A) Anse Thomas; (B) Bain du Curé; (C) Hot water discharge at sea from the geothermal power plant (source chaude du bourg; courtesy of B. Hira, ORMAT Bouillante).

In addition, the geothermal power plant in Bouillante discharges hot water at $45^{\circ} \mathrm{C}$ giving rise to the so-called sulfuric spring of the village (source chaude du bourg) and warming up the village coastline. The discharged water has a chemical composition identical to that of natural hydrothermal springs encountered at the surface or at sea (Bourdon et al. 2008 [68]).

Most of these hot springs have low flow-rates, in the order of $1 \mathrm{~L} / \mathrm{min}$, and with highest values of $\sim 10 \mathrm{~L} / \mathrm{min}$ measured at Thomas and La Lise (Lachassagne et al. 2009 [69]). Spring chemistry of the Bouillante area has waters of the $\mathrm{Na}-\mathrm{Cl}$ and $\mathrm{Na}-\mathrm{HCO}_{3}$ types; both have neutral to slightly alkaline $\mathrm{pH}$ values. The $\mathrm{Na}-\mathrm{Cl}$ waters are characterized by generally high mineral contents (Total Dissolved Solids, TDS, up to $30,000 \mathrm{mg} / \mathrm{kg}$ ) and may display high discharge temperatures, such as in case of submarine springs in front of the Pointe de 
Lézarde, and the subaerial springs, Thomas and Anse à la Barque, Cave BO-2, Tuyau, and other springs which have disappeared (Brombach et al. 2000 [46]; Figure 7). The $\mathrm{Na}-\mathrm{HCO}_{3}$ waters (e.g., La Lise and Bain du Curé) show much lower TDS values $(180-320 \mathrm{mg} / \mathrm{kg}$ ) and temperatures $<50{ }^{\circ} \mathrm{C}$ (Brombach et al. 2000 [46]). These are surface fresh waters heated by conduction (Mas et al. 2006 [76]).

The contribution of geothermal fluid, which is composed of about $42 \%$ fresh water and 58\% sea water (Sanjuan et al. 2001 [72]), is quite small in most of the terrestrial springs (mostly below 10\%). On the basis of a mean 10\% contribution of the geothermal fluid to the springs, the leakage volumes from the geothermal aquifer can thus be estimated between 1 and $10 \mathrm{~m}^{3} / \mathrm{h}$ at most (Lachassagne et al. 2009 [69]). The absence in the Bouillante geothermal fluid of oxygen isotope enrichment $\left(\delta^{18} \mathrm{O}\right)$ expected on interaction with volcanic rocks and its residual marine $\delta^{34} \mathrm{~S}$ signature suggest a high water/rock ratio in a deep relatively large and interconnected reservoir (Sanjuan et al. 2001; and Lachassagne et al. $2009[69,72])$.

\subsubsection{The Very Active Volcanic-Hydrothermal System of La Soufrière}

Apart from the Bouillante area, the most important and widespread manifestations of geothermal activity in Guadeloupe (thermal springs, fumaroles, and areas of hydrothermally altered rocks) are linked with the Soufrière massif. Active fumaroles are currently limited to the dome itself (Figure 2), with the exception of a small fumarolic area in the Matylis and La Ty river at the SE base of the dome (Figure 2), currently inactive. Numerous thermal springs are located from the base to within $5 \mathrm{~km}$ of the dome. Historical observations show that the nature, distribution, and intensity of these geothermal manifestations has fluctuated considerably over time (OVSG-IPGP, 1999-2021; Villemant et al. 2005, $2014[45,46,48])$.

\section{La Soufrière Fumarolic Field}

Volcanic-hydrothermal activity is mainly expressed as La Soufrière summit fumaroles and hot springs dispersed around the volcanic dome. Detailed field studies reveal that degassing of diffuse $\mathrm{CO}_{2}$, and $\mathrm{H}_{2} \mathrm{~S}$ to some extent, occurs commonly along the dense network of faults (Allard et al. 1998; 2014; and Tamburello et al. 2019 [43,47,77]). $\mathrm{CO}_{2}$ prevails in the gaseous emissions (about $70 \%$ of dry gas), followed by hydrogen sulphide $\left(\mathrm{H}_{2} \mathrm{~S}\right)$ (up to $29 \%$ of dry gas), sulphur dioxide $\left(\mathrm{SO}_{2}\right)(<1 \%$ of dry gas) and hydrogen chloride (HCl) (110-210 ppmv) (OVSG-IPGP 1999 on, Pedroni et al. 1999; Brombach et al. 2000; Bernard et al. 2006; and Moretti et al. 2020 [19,46,48,78-80]). The significant chlorine degassing directly through the summit (ongoing since late 1997) has resulted in visibly significant degradation of the vegetation on the dome and its immediate surroundings $(0.5 \mathrm{~km})$ as well as irritation and burns to eyes, skin, and respiratory pathways of people within a few tens to hundreds of meters downwind of the summit fumaroles (Massaro et al. $2021[81])$.

Isotope compositions of $\mathrm{CO}_{2}\left(\delta^{13} \mathrm{C}=-3.50 \pm 0.07 \%\right)$ and of helium $(\mathrm{He})\left({ }^{3} \mathrm{He} /{ }^{4} \mathrm{He}\right.$ at $\mathrm{R} / \mathrm{Ra} \sim 8$ ) (Pedroni et al. 1999; Brombach et al. 2000; Rivé et al. 2013; Ruzié et al. 2013; and Jean-Baptiste et al. $2014[46,66,67,78,82])$ confirm that the deep volatile fraction has mantle source. This gas composition, low in $\mathrm{SO}_{2}$ and high in $\mathrm{H}_{2} \mathrm{~S}$, are characteristic for a genesis in shallow, low oxygen fugacity, and medium temperature $\left(<250{ }^{\circ} \mathrm{C}\right)$ conditions, typical of hydrothermal systems fed with meteoric water scrubbing and re-equilibrating gases released by an underneath magma chambers (Brombach et al. 2000; and Moretti et al. $2020[16,46,80])$.

\section{Hot Springs and Thermal Waters around La Soufrière}

The shallow hydrothermal system of La Soufrière de Guadeloupe is confined to the Crater Amic structure inherited from a series of flank collapse events affecting the upper parts of La Soufrière-Grande Découverte volcano (Komorowski et al. 2005; and Boudon et al. 2008 [23,30]; Figure 5). The low permeability of the volcanic edifice and the 
existence of many major discontinuities in the dome and the bedrock in place generate small discrete hydrothermal reservoirs. Thus, different parts of this complex hydrothermal system are very reactive to two major disturbances: precipitation at the top of the dome which is particularly intense and the episodic input of gas from deep magma or from shallow intrusions (Villemant et al. 2014; and Moretti et al. 2020 [19,45]). Monitoring the composition and temperature of hydrothermal fluids thus provides a particularly effective technique for monitoring the evolution of magmatic activity and volcanic crises (phreatic, phreato-magmatic, or magmatic) and provides constraints for the evaluation of hazards.

The location of thermal springs follows a typical radial distribution around La Soufrière volcanic axis, where acid-chloride-sulfate hydrothermal waters are discharged in association with fumarolic emissions, characterized by the most rapid migration of steam-rich ascending fluids far to be neutralized (Brombach et al.; 2000; Villemant et al. 2014; and Taran and Kalacheva, 2020 [45,46,83]; Figures 5 and 6A).

Based again on their content of $\mathrm{Na}, \mathrm{Ca}, \mathrm{Mg}, \mathrm{SO}_{4}, \mathrm{Cl}$, and $\mathrm{HCO}_{3}$ Soufrière hot springs can be divided as follows:

(a) Bains Jaunes (BJ), Carbet Echelle (CE), Galion (Ga), Tarade (Ta), Ravine Marchand (RM), Pas du Roy (PR), and Bains Chauds-Matouba-Eaux Vives (BCM-EV) are Ca-SO waters, also transitioning to ASC waters such as in the case of Galion and Tarade because of dissolution of $\mathrm{SO}_{2}$ and $\mathrm{HCl}$ of deep volcanic origin (Figure 7; Villemant et al. 2014 [45]);

(b) Habitation Revel (HR) is $\mathrm{Ca}-\mathrm{Na}-\mathrm{HCO}_{3}$ - water (HR), likely representing a shallow water conductively heated; and

(c) Chute du Carbet (CC) and Grosse Corde (GC) are Ca-Na-Cl- waters.

Fluorine contents are always very low. Acidic waters slightly rich in $\mathrm{SO}_{4}$ can result from a mixture of meteoric water and magmatic fluids containing $\mathrm{H}_{2} \mathrm{~S}$ (Bigot et al. 1994; Brombach et al. 2000; and Villemant et al. $2014[45,46,84])$; they are all located within the Crater Amic structure. CC and GC waters could be the result of a mixture of $\mathrm{Ca}-\mathrm{SO}_{4}$ and $\mathrm{Na}-\mathrm{Cl}$ - waters similar to those found in the deep geothermal system of Bouillante on the east coast of Basse-Terre (Traineau et al. 1997; and Villemant et al. al., 2014 [45,70]). However, CC and GC waters cannot be considered as a simple mixture between these two components due to the strong enrichment in $\mathrm{Cl}^{-}$counterbalanced by $\mathrm{Ca}^{2+}$ and $\mathrm{Mg}^{2+}$ (Villemant et al. 2005, 2014 [44,45]). BCM-EV waters differ from other $\mathrm{Ca}-\mathrm{SO}_{4}{ }^{2-}$ waters by their very low $\mathrm{Cl}^{-}$content. $\mathrm{HR}$ waters could correspond to shallow groundwater with compositions close to those of regional cold sources heated by magmatic heat transfer.

Most of the thermal springs have weak flow rates, between 1 and $100 \mathrm{~L} / \mathrm{min}$. The thermal springs Chute du Carbet, Bains Jaunes, and Galion of La Soufrière area have higher flow rates, reaching hundreds of litres per minute, and the thermal springs of Matouba total flow rates of thousands. Contrary to Bouillante springs, the scenic value of many of these springs is high because of their association with natural pools and/or falls in the nearby or downstream, such as in the case of Chute de Carbet and Galion springs (Figure 9).

Carbet Echelle is an acid $(5<\mathrm{pH}<5.5)$ ferruginous source showing reddish-brown precipitates of iron oxide and hydroxide upon resurgence. It is close to the volcano summit and shows variations that well correlates with the activity of La Soufrière. Its temperature, particularly, was elevated after the 1976-1977 phreatic eruption, but then decreased to reach the current stable value around $21^{\circ} \mathrm{C}$.

Galion is a ferruginous spring displaying reddish-brown precipitates of iron oxide and hydroxide upon resurgence. Its water is strongly mineralized and acidic $(\mathrm{pH}<5)$, at a temperature currently close to $50^{\circ} \mathrm{C}$. The chemical variations of its dominant sulfatechloride and calco-magnesian composition make it a good marker of La Soufrière degassing activity outside the fumarolic area. 

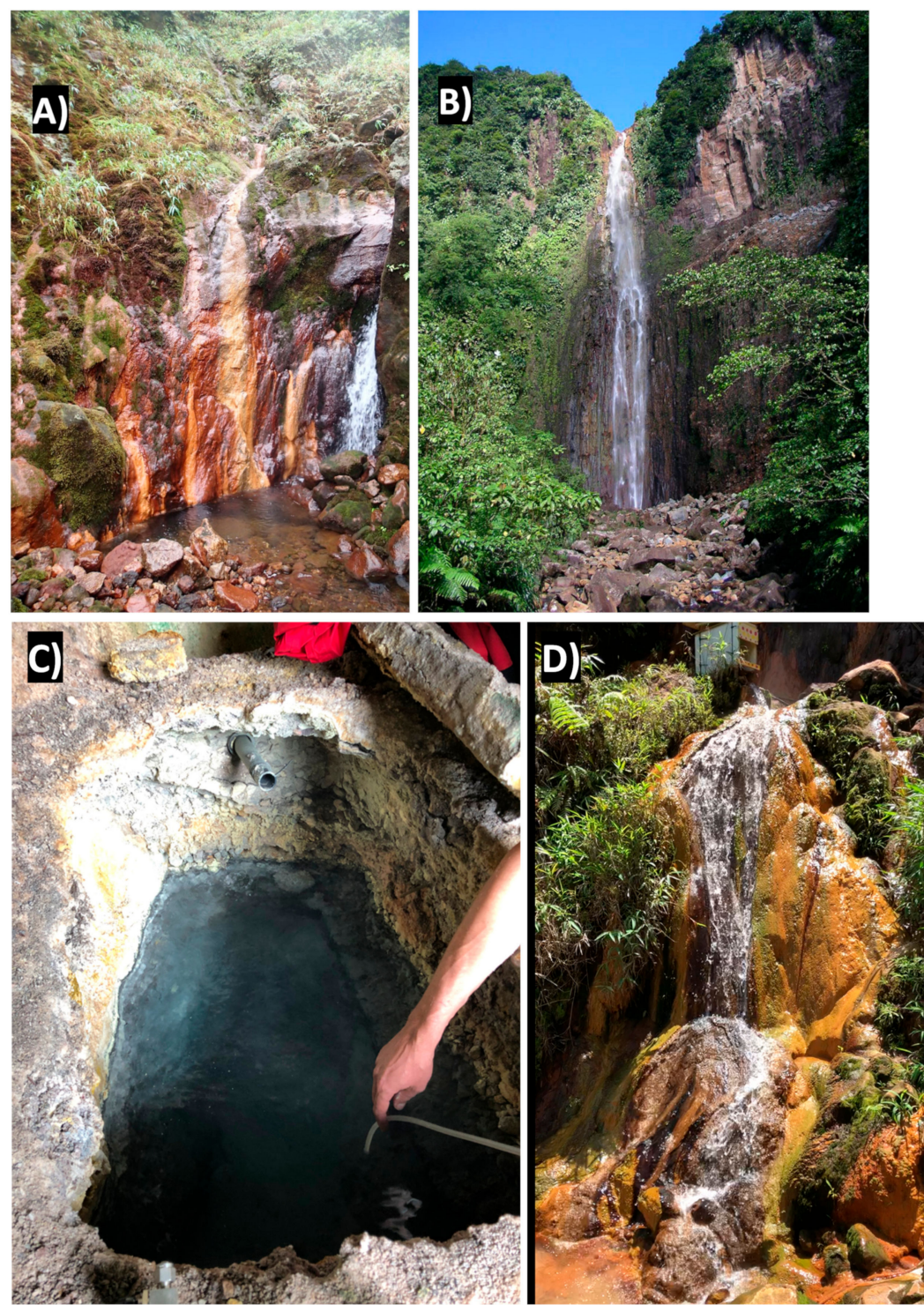

Figure 9. Images of selected hot springs from Soufrière-Grande Découverte complex (courtesy of the OVSG-IPGP). (A) Carbet Echelle; (B) Deuxième Chute du Carbet; (C) Bains Chaudes-Matouba; and (D) Galion.

Bains Jaunes (981 $\mathrm{m}$ altitude) on the western flank of the Soufrière is made up of several springs, one of which comes out in a large pool $\left(\sim 60 \mathrm{~m}^{2}\right.$ by $1 \mathrm{~m}$ of depth) in freestone that is still widely used today by hikers (Figure 9 ). It is an acid mineralized water $(5<\mathrm{pH}<5.5)$ at a temperature of $\sim 30^{\circ} \mathrm{C}$.

The hyperthermal hot spring of Matouba $\left(50-60{ }^{\circ} \mathrm{C} ; \mathrm{BCM}-\mathrm{EV}\right)$ is located about $1.2 \mathrm{~km}$ $\mathrm{m}$ from the dome of the Soufrière, on its western slope ( $1055 \mathrm{~m}$ altitude). It comes out from several points one of which was captured in 1959 to build the Matouba Hot Bath of about $10 \mathrm{~m}^{3}$ and supply the thermal spa and clinic located $3 \mathrm{~km}$ away (600 m altitude) west of the spring. It is disconnected from the main hydrothermal aquifers of La Soufrière massif, as testified by the low- $\mathrm{Cl}$ contents and the lack of chemical variations observed in other sources and correlating with La Soufrière activity. The Matouba hot waters are acid mineral waters $(5.5<\mathrm{pH}<6)$ essentially conductively heated. Some authors (e.g., Barat, 1986 [85]) suggest that the BCM-EV spring may feed the small hot spring HR, located $3.7 \mathrm{~km}$ far away at west at the contact of two Grande Découverte late lava flows, via an E-W fault.

The source of Carbet (605 $\mathrm{m}$ of height) on the eastern flank of the Soufrière, comes out close to neutrality $\left(>\sim 40^{\circ} \mathrm{C}\right)$ in the rocks next to the second Carbet waterfall to form small 
natural pools, frequently used by walkers before landslides caused by the 2004 earthquake and now closed to the public.

The Basin of Grosse-Corde is located a little lower (560 m altitude) on an artesian spring $\left(35^{\circ} \mathrm{C}<\mathrm{T}<40{ }^{\circ} \mathrm{C}\right)$ close to neutrality at the level of the Grosse-Corde river in the middle of the tropical forest.

The chemical composition of the spring waters of the Soufrière massif is regularly analysed as part of the monitoring of volcanic activity in the Soufrière. Certain sources, among the most frequented by the population, are also the subject of surveillance carried out for health safety purposes related to the Naegleria fowleri amoeba, responsible for primary meningoencephalitis. However, the flora and fauna of these sources have never been the subject of a targeted study.

High temperatures from some sources are likely to favour bacteria and cyanobacteria, which are an essential part of the biofilm. Although the biodiversity within each of these categories is low, the cyanobacteria, bacteria, and archae appear to be dependent on specific environmental conditions at each hot spring site and have never been observed in the rest of Guadeloupe or Antilles on a larger scale. Their study therefore made it possible to increase the known biodiversity of Guadeloupe (Lefrançois et al. 2016 [86]).

\subsubsection{Other Thermal Springs: Dolé Area, Ravine Chaude, and Sofaia}

The thermal springs in the Gourbeyre sector (Capes and Dolé springs) are located at 200-300 m above the sea level, $\sim 0.5 \mathrm{~km}$ of distance each other; $6 \mathrm{~km}$ south of Soufrière dome and not directly linked to its hydrothermal system (Figure 5). Springs are located in andesitic formations, related to a E-W fracture system, close to the contact beween the young La Soufrière complex and the ancient Mounts Caraibes volcanic massif.

The Capes and Dolé spring systems source the most frequented basins of Guadeloupe by tourists and the local population. The Capès spring is made up of seven resurgences stepped in balcony ( $20 \mathrm{~m}$ vertical drop over $200 \mathrm{~m}$ long), below the local road 7 at the Dolé site. The southernmost emergences are known as Bains des Amours and Bain de Capes. The Bain des Amours is a tiled pool of approximately $10 \mathrm{~m}^{3}$ recently fitted out for public while the Capès Bath, supplied by a different resurgence located a few tens of meters away, remains a small natural basin not developed in rock and under vegetation (Figure 9).

The spring of Dole which allowed the creation of the first spa establishment in 1842, which evolved in 1920s in a hotel for people suffering from rheumatism and whose activities ceased after the second world war, consists of three resurgences above the local road 7 at the same place called Dolé. The two resurgences located farther north of the emergence have been captured since longtime to supply a first large concrete basin $\left(60 \mathrm{~m}^{3}\right)$ near the source, currently very poorly maintained and buried under the vegetation and a second basin of about $15 \mathrm{~m}^{3}$ below, in proximity of the local road (Figure 9). The third resurgence feeds several natural pools under the vegetation and another concrete basin (Figure 10A). Besides, around $15 \%$ of the natural flow is also captured by the bottling plant installed on the site since 1968 (Jeremie and Pascarelli, 1992 [65]).

The bulk water discharge of these two spring systems is high, $>10,000 \mathrm{~L} / \mathrm{min}$, and their temperatures is in the $31-34{ }^{\circ} \mathrm{C}$ range (Jeremie and Pascarelli, 1992; and Bourdon et al. $2008[65,68])$. Waters are of the $\mathrm{Ca}-\mathrm{HCO}_{3}$ type (Figure 7 ) characterized by dissolved $\mathrm{CO}_{2}$, and represent neutral shallow meteoric waters conductively heated because of their proximity to the Soufrière system.

The source of Ravine Chaude $\left(\mathrm{T}<35{ }^{\circ} \mathrm{C}\right)$, in the centre of the Basse-Terre island, in the municipality of Lamentin at a height of $110 \mathrm{~m}$ (Figure 5) comes out from andesitic lava flows surrounded by alluvial conglomerate facies. Water is low-mineralized, belonging to the bicarbonate-sodium facies (Bézèlgues-Courtade and Bes-de-Berc, 2007 [5]; Figure 7). Isotopic data confirm the shallow meteoric origin, with both $\mathrm{CO}_{2}$ and $\mathrm{H}_{2} \mathrm{~S}$ of organo-genic origin (Bourdon et al. 2008 [68]) The resurgence that once discharged water in a small natural basin has been captured in the 1960s to install a first spa, then renovated in the 1990s with a balneotherapy centre then closed in 2005 and which is currently being redeveloped. 
Today the water of the source, whose flow-rate is $>2000 \mathrm{~L} / \mathrm{min}$, is captured in a large concrete basin about $15 \mathrm{~m}$ in diameter, $1 \mathrm{~m}$ in deep.

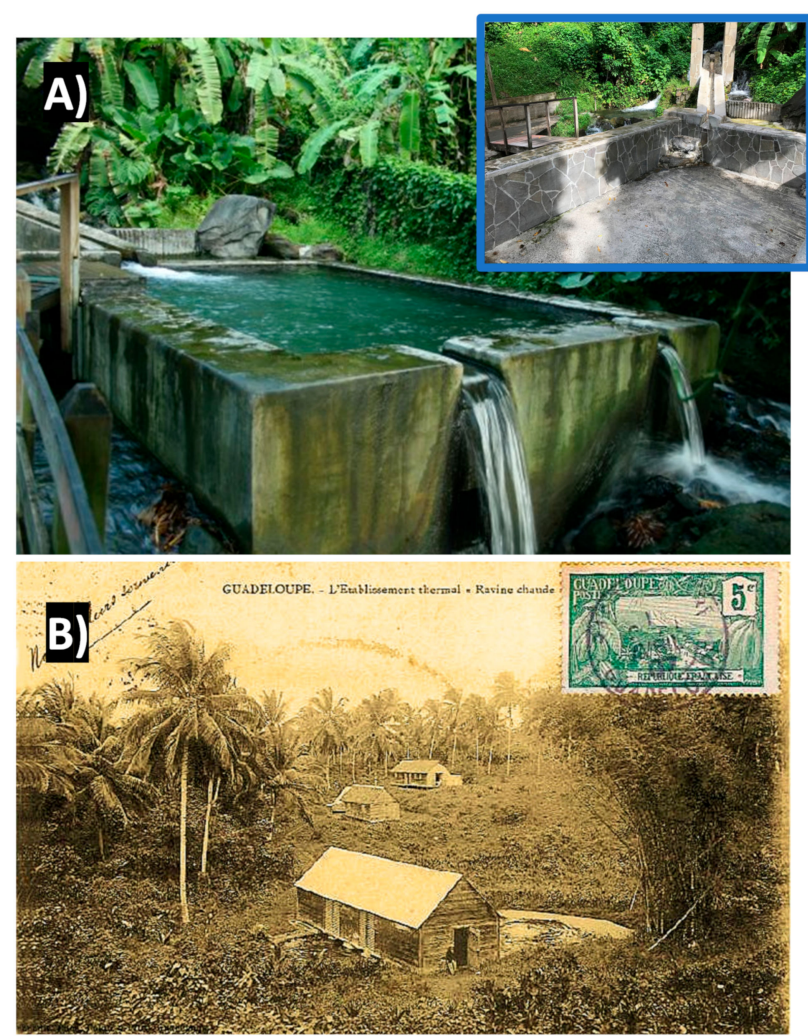

Figure 10. (A) $15 \mathrm{~m}^{3}$ basin fed by Dolé hot spring waters. In the inset, the current empty basin status due to the diverted streamwater for safety reasons related to the ongoing andemic. (B) Historical postcard (dated 1907) of the Rivière Chaude thermal bath.

Sofaia is located in the northern side of Basse-Terre, in the municipality of Sainte-Rose at a height of $300 \mathrm{~m}$ (Figure 10B). With a flow-rate of $\sim 40 \mathrm{~L} / \mathrm{min}$, it emerges from the ancient volcanic formations of the Northern Chain and would have appeared following the $\mathrm{M}_{1} 8$ earthquake of 1843 (Bourdon et al. 2008 [68]). First conveyed in two public pools, it is now distributed in the form of an installed shower ramp on woodwork. Its origin is not related to the presence of deep buried magmatic bodies, but related to circulation at some depth from the recharge area to the emission point after conductive heating. This gives $\mathrm{Na}-\mathrm{SO}_{4}$ waters at $31^{\circ} \mathrm{C}$ bearing $\mathrm{CO}_{2}$ and $\mathrm{H}_{2} \mathrm{~S}$. The former has a biogenic origin, whereas the latter is likely due to leaching of hydrothermal pyrite $\left(\mathrm{FeS}_{2}\right)$ and reflecting acid and reduced conditions (Bourdon et al. 2008 [68]).

\section{Discussion on Perspectives and Challenges for Resilience and Sustainability}

The volcanic-hydrothermal geodiversity presented so far is a unique form of richness for Basse-Terre and the whole of Guadeloupe. There is a great potential for an integrated plan of sustainable and resilient development which can be a model for other volcanic islands. Two main axes to the integrated plan are here identified for further development and discussion: (a) a "total" natural risk laboratory, also in charge of the quali-quantitative monitoring of groundwaters, and (b) diffuse co-generation of energy, particularly geothermal energy. A third axis concerning economic sustainability, related to the development of tourism around thermal waters, well-being and related measure activity can also be identified. The latter, however, is beyond the scopes of the present paper although central for socio-economic empowerment within a prospective resilient, sustainable and regenerative (i.e., circular) economic model. 


\subsection{A Unique Natural Laboratory for Climate-Volcanic Activity Interaction on Geodiversity, Biodiversity, and Ecosystem Response}

Hydrothermal systems are dynamic habitats where geological, chemical, and biological processes are intimately connected. Springs, geysers, and fumaroles have a high scenic power, especially because of their particular landscape and chromatic power. Both are the results of alteration by percolating fluids that transforms primary minerals in lavas to weaker and erodible secondary products such as clay minerals. La Soufrière volcano is then impacted by an extensive argillitic alteration (Salaun et al. 2011; and Heap et al. $2021[41,73])$ that results from the bottom-up hydrothermal alteration but also the topdown climate-driven one promoted in the so-called critical zone of this complex tropical environment (Dessert et al. 2015 [55], and references therein). In particular, as the critical zone is defined as extending from the lower limit of weathered bedrock or freely circulating groundwater to the top of the vegetational canopy, we see that because volcanic hydrothermal systems transfer heat and matter to the surface, regulating chemical fluxes, they cause modifications or even damage to the ecosystems around them. There must be a link and a feedback between biodiversity distribution and the spatio-temporal distributions of emissions and their environmental impact are determined by the complex interaction between fluid flows and the opening/closing (sealing) of network fractures permeable to hydrothermal fluids.

At La Soufrière, a partial view of fluid flows has been captured and modelled from monitoring data (thermal, seismic, and deformation) and using a robust structure model, obtained by a new imaging technique, muography (Gibert et al. in press and references therein [87]). The variations in density in the structure, correlated with the seismic activity of the sub-surface and with the heating of the surface highlights the temporal and spatial instabilities of the system. For example, the progressive activity increase at La Soufrière is accompanied by well visible phenomena such as (1) the appearance of new fumarolic areas (Moretti et al. 2020 [19]), (2) the increase of the area of anomalous thermal release (Jessop et al. 2021 [50]), and (3) $\mathrm{CO}_{2}$ soil degassing (Allard et al. 2014; and Tamburello et al. $2019[47,77])$. This evolution has produced a dramatic decline of the vegetation, then its complete disappearance in regions where fumarolic activity and gas and heat release from soil progressively establishes.

Geochemical monitoring can thus be coupled to biogeochemical monitoring of gases and trace elements, typically based on lichens and mosses which are natural bio-accumulators (e.g., Bonanno et al. 2012 [88]). Another case of great interest is provided by the biofilm that develop in and in proximity of hot springs and which is constituted of diatoms, bacteria, cyanobacteria and Archaea (Lefrançois et al. 2016 [86]). The peculiar adaptation of some taxons to specific temperature, $\mathrm{pH}$ and conductivity conditions in silica-rich aquatic environments can be used for monitoring purposes. For example, diatom bioindicators are primarily used for the assessment of the water quality, however, some can be better targeted to monitor geochemical changes occurring at hot springs (Bourrelly, 1981; and Tudesque and Ector, $2002[89,90])$.

Besides, developments in plant neurobiology (e.g., Baluska, 2006; and Baluska and Mancuso, 2009 [91,92]) clearly show that plants react rapidly to physical and chemical perturbations of the subsoil environment, such as interstitial pressure and osmotic forces, $\mathrm{pH}$, temperature (e.g., Gurovich and Hermosilla, 2009; and Baluska and Mancuso, 2009 [92,93]). Plants have a fine and sophisticated neuronal system covering sensorial as well as communication aspects, which make them able to cope with rapidly changing environments (Baluška et al. 2006; Barlow, 2008; and Baluska and Mancuso, 2009b [94-96]). Therefore, monitoring plant activity, particularly electrophysiology (e.g., Volkov 2012; and Gurovich and Hermosilla, 2009 [93,97]) and root tropism signals (Muthert et al. 2020 [98]) in the hydrothermal-volcanic environment may highlight anomalous stress conditions associated with the ongoing unrest and offer in perspective innovative tools for early warning.

Moreover, in an integrated environmental approach to the qualitative and quantitative state and pressure-impact relationships aimed at the protection of groundwaters as 
demanded by the Water Frame Directive (hereafter referred to as WFD) 2006/118/CE, the monitoring of the volcanic-hydrothermal environment should have a special place. In fact, fluctuations related to endogenous activity may determine important variations of the hydrogeochemical backgrounds of metals (Ratsimihara et al. 2014 [99]). It is, in fact, possible that natural (geochemical) backgrounds (of groundwaters at La Soufriere) challenge quality standards of the WFD. Besides, it is possible that anomalous departure from the geochemical background are due to the arrival of deep (magmatic) fluids injecting into the hydrothermal system and consequent water-rock interaction, with alteration of the thermal regime and flow-rate. These anomalies can be recurrent or follow transitory episodes of accelerated unrest like in 2018 (Moretti et al. 2020 [19]), and ideally anticipate major events of natural pollution (i.e., volcanic eruptions). Groundwaters are an asset that has first to be fully characterized in the south Basse-Terre because volcanic reactivation at depth may produce endogenous contamination of deep aquifers, whereas the shallow aquifers are impacted by anthropic activities. It is then mandatory to have $(a)$ a full hydrogeological model of deep water bodies of Basse-Terre including hydrothermal groundwaters, and $(b)$ the hydrogeochemical setting of deep waters and how volcano-related activity may shifts in that setting. This implies that the quality of water is highly variable, as shown by the elevated concentrations in chlorides, sulphates, iron and manganese (Ratsimihara et al. 2014; and Villemant et al. $2014[45,99])$.

Seemingly, one major perspective of development around the hydrothermal geodiversity of the Basse-Terre island, particularly its active volcanic sector, is then related to the effect that variations in the hydrothermal systems may have on the critical zone and the added effects related to climate change. In parallel, climate change and its effects could be observed looking at hydrothermal activity (temperature, fluxes, and chemistry) at the different sites and the response of their ecosystems and biodiversity. The monitoring of groundwaters is compulsory to fully conceptualize processes that relate to ascent of steam to summit fumaroles and which also carry mineral resource for nutrients and which also tune mineral resources and nutrient availability for those many ecosystems which also contribute to the natural water quality.

It is evident that such integrated approaches imply the constitution of a total observatory for telluric risks, climate change, and ecosystem response integrating emerging monitoring practices (Gibert et al. in press and references therein [87]) to existing ones for seismic activity, deformation, and fluid chemistry. Besides, the forms of Participative Environmental Monitoring (an example of citizen science; Dickinson et al. 2012; and Roy et al. $2012[100,101])$ can be envisioned and must be favoured and promoted, as they ensure a capillary monitoring in time and space and a high amount of data to exploit. The very large amount of data to process would be also one reason to promote the adoption of Artificial Intelligence and Data Mining approaches in a bulk perspective of risk assessment and approach to resilience, as discussed later in Section 4.3. It is important to remark that the "total" observatory is a major long-term investment, as it allows to forecast major events and with its authoritative support take the appropriate decision. It is primarily an instrument of risk mitigation, for which the investment is much lower than any utopic and cost prohibitive refurbishment of the territories existing infrastructures and goods aimed at ensuring prevention. In Guadeloupe the attention to the interactions between volcanic geosystems, biodiversity, and ecosystems is becoming high, also stimulated by funded projects (e.g., https: / / www.inrae.fr/actualites/immerge-comprendre-limpactmulti-environnemental-retombees-volcaniques-sahariennes-guadeloupe, accessed on 30 September 2021) and may represent an embryo for the durable synergetic activities of the total risk observatory of bio- and geodiversity.

Volcanic islands (and other SIDS) are natural risk attractors. Despite all their anthropic connections, particularly urban ones, being smaller in scale, their bulk vulnerability is high because of the limited territorial extent and the surrounding seas/oceans. This strengthens the need of an integrated observatory coordinating all the monitoring (and other related activities) about volcanic-hydrothermal systems, the critical zone, the associated ecosystems 
in relation to their surrounding geology and the effects of climate change. Considering that the critical zone is, by definition, the interface at which mass and energy are exchanged between lithosphere, pedosphere, biosphere, and atmosphere, understanding and monitoring the coevolution of physical and biological systems result in societal benefits and fosters sustainability. Focusing more strongly on the roles of weathered bedrock, soils and soil processes, soil hydrology, and longer-term hydrothermal and topographic processes would result in improved natural resource management. The fragility of volcanic-hydrothermal geosystems and ecosystems results in highly-sensitive geo- and bio-markers to endogenous and exogenous forcing. Thereby, offering an opportunity to improve Guadeloupe resilience, as discussed later.

\subsection{Energy, Particularly Geothermal}

Energy is a major issue for SIDS. In Guadeloupe the 2019 lower requirement was $\sim 10,000$ GWh and about $94 \%$ of energy consumption is sustained via imported and fossil fuels (OREC, 2020 [102]). Energy, particularly the local production of renewable energy (about 380 GWh in Guadeloupe, 22\% of the electricity demand, i.e., 1726 GWh; OREC, 2020) is one key of effective resilience. Policies have been implemented for renewable energy strategies (https: / www.guadeloupe.gouv.fr/Politiques-publiques/Environnement/Programmationpluriannuelle-de-1-energie-PPE-2016-2023-de-la-Guadeloupe/Mise-a-disposition-du-public-dela-programmation-pluriannuelle-de-l-energie-de-la-Guadeloupe, accessed on 30 September 2021) that include reduction of consumption (especially for transportation), biomass wasteto-energy valorisation, ocean wave energy, and, particularly, geothermal energy. All of these represent important source of employment at the regional scale and thus SIDS socioeconomic empowerment, with geothermal energy requiring special focus as it keenly relates to the water resource and its management.

The Bouillante geothermal power station, tapping a high-temperature $\left(260^{\circ} \mathrm{C}\right)$ geothermal field, is for almost 40 years the first capacity of production of geothermal electricity in France and, paradoxically, it is so far the only installed capacity in this area of the Caribbean (Sanjuan et al. 2011 [73]). Seven wells were drilled between $322 \mathrm{~m}$ and $2504 \mathrm{~m}$ deep: three wells are used for production, two were abandoned, and two are reservoir pressure observation wells (Demians D'Archimbaud and Surcin, 1976; Lachassagne et al. 2009; and Traineau et al. $2015[69,79,103])$. The fluids produced by producing wells consist of about 58\% seawater and 42\% surface fresh water (Sanjuan et al. 2001 [73]). Current geothermal production is based on a $15.5 \mathrm{MW}$ plant in Bouillante with two units of 4.5 and $11 \mathrm{MW}$ that are supplied by three geothermal wells (BO-4, BO-5, and BO-6; Figure 5; Traineau et al. 2015 [79]) and which produced in 2019, 109.5 GWh, or 6.3\% of produced electricity (including importation) (OREC, 2020 [102]). Steam is taken between 500 and $1000 \mathrm{~m}$ deep via two sampling wells and part of the steam is released in liquid form at sea and another is reinjected into the subsoil via a dedicated well. The energy production hardly causes any loss of water mass. A partial underground fluid reinjection is operational, since 2014, with benefits for further preventing environmental pollution from geothermal fluids (chemical and thermal), for providing pressure support to the reservoir, mitigating the risk of pressure drawdown and boiling, and in preventing or reducing subsidence (Kamila et al. 2021; and Traineau et al. 2015 [79,104]). The perspectives are to increase the exploitation of the Bouillante geothermal field, in order to attain a potential of $50 \mathrm{MW}$ by 2030 (ADEME, 2020 [105]).

Plans for exploration nearby the Soufrière volcano were presented under the scientific auspices of a major project aimed at improving the understanding of fractured geothermal reservoirs (https:/ / geotref.com/wp-content/uploads/2016/05/joe_20160520_0116_0009 .pdf, accessed on 30 September 2021), which are the object of discussion and further study. Major issues are the compatibility of such a plan with the (1) risk issues generated by hydrothermal-volcanic activity and its monitoring and (2) the environmental risk put on deep groundwaters and their quality. How these two factors may increase both the telluric (volcanic and seismic) and environmental risk, and how they can impact, either negatively 
or positively, the bulk resilience capacity of the Basse-Terre Island is not an argument of discussion of this paper. Besides, an inter-island project plans to connect Dominica, which has a geothermal potential of $120 \mathrm{MW}$, to Guadeloupe and Martinique and distribute 40 MW each (ADEME, 2020 [106]). Geothermal plants contribute significantly to a secure electricity supply of the island as well as to a decrease in its production cost (in Guadeloupe most non-geothermal electricity is generated by burning fossil fuels), and to a concomitant reduction in greenhouse gas emissions. Power generation and supply are, in fact, central for quick post-crisis recovery and responsive resilience policies. However, these also need decentralization of production sites and stocks as well as a diversification of energy sources. Again, the fate of all these projects is not matter of study here, but indicate an augmented sensibility for the energetic autonomy of Guadeloupe, which is a key factor for successful resilience policies.

Given the number of rivers in the Basse-Terre sectors, the high flow-rate favoured by rainfall (Figure 4), and the high number of available hydraulic jumps, here we speculate that a network of diffuse micro- and mini-hydropower generators (e.g., Elbatran et al. 2015 [106]) as a viable solution for both sustainable development and resilience capacity. Depending on the consequent cost/benefit analysis at given sites and bio-preservation issues, this form of energy recovery may be a very attractive possibility, with small additional costs for managers and investors. Considering the relatively dispersed urbanization in the Soufrière surroundings, which includes small agglomerations or even lone houses, networking hydropower generators could be a successful support for a sustainable electric power supply.

\subsection{From Volcanic-Hydrothermal Geodiversity to a Responsive and Resilience-Driven Plan of Sustainable Development}

The basic difference between sustainability and resilience is that sustainability refers to developing and/or maintaining social, economic, and environmental conditions opportunities over the long-term whereas resilience refers to the recovery of the whole system from one or more shocks (Régibeau and Rockett, 2013 [107]), such that it may restore and retain in the long-term its functions, structure, identity, and feedbacks (Holling, 1996; and Walker et al. $2004[108,109])$. Therefore, a sustainable system must not be necessarily resilient or may display different resilient behaviours depending on the kind of shock, the speed of recovery, and the level of bulk performance after shock. The choice of performance parameters to measure resilience are, of course, quite arbitrary and in a perspective broader than what is discussed in the following, because they are also related to the acting welfare system and how this is ruled by the local governance. For example, assuming that the governance rules the welfare to ensure sustainability and resilience, we may conclude that the wellbeing is the main outcome of interest and also a performance measurement of the governed co-evolving system of humans and their environment (Régibeau et Rockett, 2013 [107]). Vihar and Doon (as reported by Régibeau and Rockett, 2013 [107]) show that given two similar community-environment pair, the one with more rigid response has the lower level of well-being, as measured by many performance outcomes, including satisfaction (Régibeau and Rockett, 2013 [107], and references therein) or parameterized by indexes such as the Human Development Index (United Nations Development Programme; http: / /hdr.undp.org/en/statistics/hdi/, accessed on 30 September 2021) or similar ones. Well-being is a key factor to generate sustainable development and a major ingredient of the attractiveness of a territory. Geodiversity and, particularly, the volcanic-hydrothermal geodiversity are obviously valuable assets for maintaining, enhancing, and, in this case, recovering well-being and attractiveness.

The integration of resilience and sustainability has been widely and qualitatively discussed in the literature (e.g., Achour et al. 2015; Marchese et al. 2018; and references therein $[110,111])$. Here we use the classic sustainability three-circles tripod (Figure 11) to include specifically for volcanic SIDS the axes discussed above in Sections 4.1, 4.2 and 4.3. The initial, or equilibrium, tripod is sketched in Figure 11A as showing an equilibrium situation involving the three compartments of society, economy, and environment, rep- 
resented as circles whose intersection defies sustainability. The equilibrium condition is arbitrarily represented by same size of the circles and equal distances between their centers. Some specific aspects are selected that are relevant for SIDS: (1) Sound Ecological Principles and Maintenance of Geodiversity and Biodiversity for Environment; (2) Efficient Use of Water and Geothermal Resources for the Environment-Economy intersection; (3) Robust Economic Practices, Agriculture and Tourism Assets for Economy; (4) Safe and Healthy Surrounding, Optimal Land Management, and Coping with Natural Risks (both fostered by the all-risk observatory) for the Environment-Society intersection; (5) Good Life Standard for Individuals and Communities (Residents plus Tourists) for Society; and (6) Economic and Social Equity for the Economy-Society intersection. Sustainability is defined by the common intersection of the three circles.
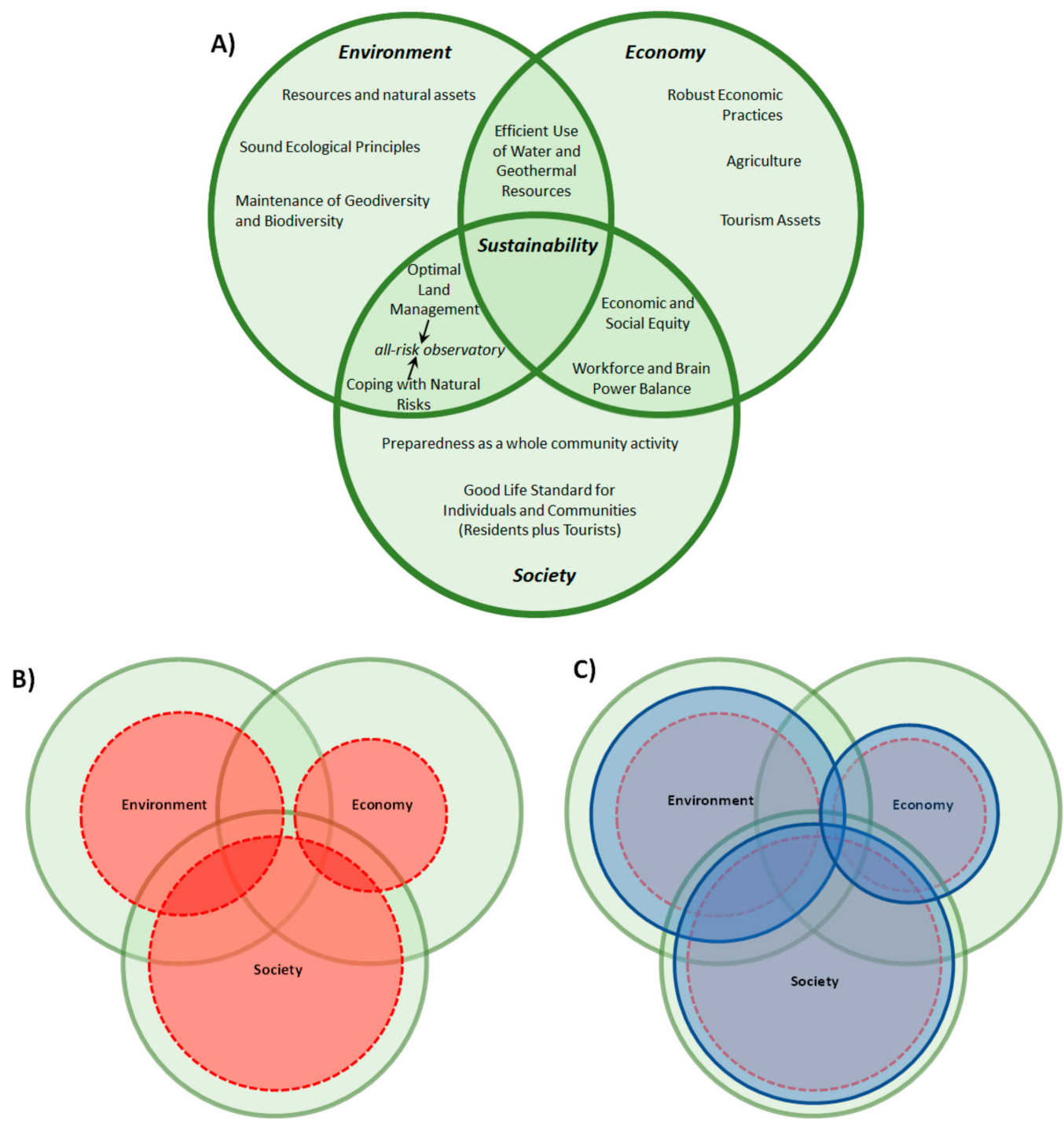

Figure 11. (A) The sustainability tripod made resilient, modified from Gary et al. (2005) [112]. The sustainable tripod time can shrink differentially for the three compartments right after a sudden shock such as a volcanic eruption occurring on small and relatively territories, such as SIDS. (B) applies conceptually to a low-resilient or even anti-resilient SIDS system, with the shock making the sustainable set of conditions to disappear. Lack of preparedness appears as a major factor. (C) refers instead to a SIDS system which has implemented policies for preparedness and recovery discussed in the text and which allow quick and sustainable recovery.

In this representation we should also note that the volcanic-hydrothermal geodiversity is a resource that may produce monetary value via the tourism industry but it is also a part 
of the local and regional geoheritage. As such, its cultural and scientific value strengthen its nature as a "public good", whose benefit goes beyond residents. Due to its cultural aspect, maximising the resource value therefore demands a distribution of economic (monetary, job employment) benefits island-wide, thereby globalizing its cultural capital and site appeal. This latter will stand almost unaltered after a main shock (e.g., volcanic eruption) and will greatly help recovery.

\subsubsection{The Challenge of Hydrothermal and Volcanic Hazards}

Of upmost importance in the management of the stricto sensu volcanic risk is the ORSEC emergency plan "volcanic phenomena" (established with decree 9 CAB/SIDPC in 2018; https: / / www.guadeloupe.gouv.fr/Politiques-publiques/Risques-naturels-technologiques-etsanitaires /Les-risques-telluriques-en-Guadeloupe / Activite-volcanique-de-la-Soufriere-deGuadeloupe-et-sismicite-regionale/Le-plan-ORSEC-Volcan, accessed on 30 September 2021), counting four $(0,1,2$, and 3$)$ scenarios. In this plan the magmatic eruption of 1530 is representative of the hazards generated by an explosive eruption of medium magnitude. Although, several more intense explosive eruptions have been identified at La Soufrière in the last 10,000 years. Even though less intense than magmatic eruptions, the more frequent non-magmatic eruptions of La Soufrière can generate small pyroclastic flows (Esposti Ongaro et al. 2020 [113]), lateral directed explosion with blast (Boudon et al. 1984 [114]) and, of course, tephra fall (e.g., volcanic bombs, lapilli, and ash). The state of the art of knowledge of phreatic and hydrothermal eruptions shows that they are typically frequent and sudden, that their precursor signals are frequently absent or even few and equivocal, that they are characterized by a very long duration and variable intensity, and that the associated phenomena are very varied and can be particularly dangerous in the proximity (Barberi et al. 1992; Christenson et al. 2010; and Kato et al. 2015 [115-117]). It is worth noting that the vast majority of phreatic eruptions are not systematically followed by a magmatic eruption. On the other hand, any magmatic eruption of which the precursor signs are more numerous and marked will be preceded by a phreatic eruption.

The current situation of the volcano (alert level: vigilance, coded by the yellow colour on a scale of four: green or no-alert; yellow, orange, or pre-alert; and red or alert) is considered by the OVSG-IPGP as corresponding to a low probability of eruptive activity on the short-term, a fact which, however, does not exclude but instead implies that onset of sudden changes may occur at any time. Recent studies have clearly pointed out that magmatic processes prior to eruption can occur on relatively short timescales at La Soufrière de Guadeloupe and can rapidly produce large-scale eruptions on short timescales (Metcalfe et al. 2021 [118]) Given the increase in seismic and fumarolic activity recorded since February 2018, further intensification of phenomena is likely to occur in the future. The gaseous emissions in the vicinity and leeward of the main summit fumaroles have, since 1998, proven risks of irritation and burns (eyes, skin, and respiratory tract).

La Soufrière volcanic and hydrothermal landforms and processes are well-known for being attractive destinations for geotourism, ecotourism, and adventure tourism. Attracting even more tourists to volcanic-hydrothermal sites and ensuring their optimal safety are, of course, opposite needs, which demand compatibility with the scenario 0 of the ORSEC emergency plan. The evolution of the anomaly zone at the summit (ground heat propagation; Jessop et al. 2021 [50]; recrudescence of fumarolic activity with appearance in time of new centres of emission and projection of mud and fragments, Moretti et al. 2020; and Le Gonidec et al. $2019[19,119])$ the signs of the impact of sulphur and acid gases on the ground and on the vegetation, bulletins) was considered within the specifications of scenario 0 of the ORSEC plan. The Préfecture de Guadeloupe with the decree $n^{\circ} 2019 / 001$ CAB SIDPC of 14 January 2019 then instituted regulated access to the top of the Soufrière volcano, based on the identification of a security perimeter and the prohibition of any unauthorized person crossing it.

As described by Erfurt-Cooper and Cooper (2010) and Erfurt-Cooper (2018) [120,121], direct risks are such and similar sites are multiple: other than those related to eruptive 
explosive (magmatic and/or phreatic) activity, there are direct risks related to unrest and that involve the Tarissan acidic crater pit and, of course, fumaroles and vents that are prone to geysering and projection of rock fragments and acidic mud at nearly at any time, that can lead to small phreatic eruptions. Moreover, there is a plethora of collateral risks in a hostile and solicited hydrothermal environment, such as hiking accidents, sudden weather changes, fog, mass movements (rockfalls, mudflows, and landslides), sinkholes, getting lost, toxic gas emissions, thermal burns from hot springs, and altitude sickness. For example, ground and soil instability is a recurrent phenomenon, highly dependent on the interplay of exogenous and endogenous forcing factors such as (1) conspicuous rainfall seasons and (2) weathering and hydrothermal alteration of volcaniclastic deposits that leads to low physical shear strength. These factors determine that above a relatively impermeable horizon conditions, the (rain-driven) reduction of soil suction (or the increase of pore-water pressure in saturated soils) can trigger the liquefaction and remobilization of unstable terrains (shallow slides to debris flows and mud flows).

These factors can disrupt tourism in volcanic-hydrothermal areas of La Soufrière, particularly if in combination with extreme weather conditions due to the cyclone season. However, the likely impact of risk conditions on geotourism is unpredictable, because visitors are attracted by volcanic and geothermal activity, even before, during, and in post-crisis phases (Prideaux, 2004; Santana, 2004; and Cooper and Erfurt, 2007 [122-124]). Unique environments such as active volcanic and geothermal areas are potentially dangerous but also highly demanded for tourism and, as remarked long ago by Perry and Lindell (1990) [125], " ... volcanic risks are intimately related to the beauty and recreational quality of the area ... ". The Basse-Terre Island, and, particularly, the Soufrière-Grande Découverte massif conform perfectly to the above statement.

\subsubsection{The Challenge of the Volcanic Shock Consequences}

In Figure 11B, we picture the volcanic shock consequences on a low-or even antiresilient SIDS system as an alteration of circles' size, which reduces overlapping areas and makes the common sustainability area to disappear. Resilience must in fact be seen as the capacity to re-establish sustainability as quick as possible, and to make performances of the sustainable socio-economic-environmental SIDS system even more performing on the long-term after the shock (Marchese et al. 2018 [111]). Based on our previous digressions, we show in Figure 11C how resilient policies may efficiently increase preparedness and the post-volcanic shock recovery if they include:

(a) The total natural risk observatory with its continuous and participative monitoring of geodiversity and biodiversity and evolution related to short-term and long-term natural hazards;

(b) The rapid restoration of the energy supply, based on stock but also on the utilization of diffuse power sources related to geothermal energy and water; and

(c) Quick deployment, supplying and provisioning of needed livelihood and stocks, particularly water owing to the use of well-characterized strategic deep groundwater resources.

The blue circles in Figure 11C have, in fact, larger size than red circles in Figure 11B, leading to a rapid recovery of sustainability. In our representation, the Economy compartment will suffer more than the other two, but less than in the case of Figure 11B mainly because of the rapid restoration of the energy supply, based on efficient use of water and geothermal resources. The utilization of a network of energy nodal sources would also favour the local treatment of foods, mostly imported, particularly from the agri-food sector. All this drives again our attention to the strategic importance of the inland Basse-Terre waters and energy assets, which must be sustainable and not over-exploited in normal times. Their preservation is, in fact, needed for future generations in the context of climate change, and as shown here they play strategic role as a stock or reserve for water supply during a major and sudden crisis like a volcanic eruptions. Similarly, the Society compartment will directly benefit of the rapid energy restoration and clean water supply, 
whereas the Environment compartment will take advantage of the development of the total observatory for natural risks. The latter (1) develops and applies the knowledge of the responsiveness of the physical environment and its resources, allowing the preservation of Environment, (2) reduces the short-term risk via a forecasting as precise as possible, and (3) in the long-term contributes to the natural, human, and social capital regeneration via integrated research and development initiatives.

Resilience always has a cost, which should not be conflated to increased costs guaranteeing increased resilience. For instance, an eruption of La Soufrière comparable to that of $1530 \mathrm{AD}$ (VEI $\sim 4$ ) is completely disruptive to infrastructures and social organization and would require the evacuation of large sectors of the Basse-Terre island. A restoration of the pre-shock conditions has too elevated costs to be feasible and implies an almost full reset of the local socio-economic model. On the contrary, eruptions such as the 1976-1977 (VEI 2) might be fully managed at a local and/or regional scale for its whole duration at a comparably limited cost mainly determined by the disruption of activities in the close surroundings of La Soufrière ( $2-3 \mathrm{~km}$ of radius; Esposti Ongaro et al. 2020 [113]) and, if necessary, temporary evacuations of the resident population. This goes beyond the scopes of this paper, but it is clear that local responsive policies should then be able to include the displacement, by zonal sectors, of some activities and businesses, such as tourism, wellbeing and agri-food activities

\section{Conclusions}

Like biological diversity, geodiversity constitutes an important element of the natural heritage of Guadeloupe, whose intrinsic, cultural, aesthetic, functional, educational and/or scientific values must be preserved and transmitted to future generations. Basse-Terre island and, particularly, the volcanic-hydrothermal geodiversity of La Soufrière-Grande Découverte complex offer new perspectives for tackling forecasting of eruptive phenomena that arises from combining Earth and Life sciences through biological, geophysical and geochemical approaches.

The feedback effects involving hydrothermal system, which is subject to volcanic forcing, and the critical zone, which is highly dependent on hydrometeorological forcing and climate change, make La Soufrière de Guadeloupe a unique site in the world: its size and format, due to presence of a volcanic dome are highly suitable to make of La Soufrière a natural laboratory in which instrumental networks can be deployed for the monitoring of ecosystems associated with volcanic-hydrothermal manifestations. One step forward is surely the understanding of the feedback occurring between endogenous (e.g., magmatic supply of heat and gases) and exogenous factors (rainfall and climate-change-induced changes on the water bodies), which, particularly, impact critical zone processes. This feedback affect aquifers and the water resource. This water resource is mainly related to La Grande Découverte-La Soufrière complex, the main supplier for whole Guadeloupe, where multiple aquifers are at different degrees invested by the deep two-phase, volcanichydrothermal dynamics as well as by the infiltration of rainfall affected by weather features and climate change. Therefore, bottom-up deep volcanic-hydrothermal forcing factors and top-down critical zone processes contribute to the quali-quantitative state of groundwaters.

It is, thus, mandatory to frame the continuous assessment of the groundwater resource in a unique perspective within the proposed all-risk observatory valuing (1) geophysical risks and particularly the volcanic one to track and forecast the medium-term and longterm effects of volcanic unrest via the characterization and monitoring of the hydrothermal system and its activity, (2) the local impact of climate change and its effects on critical zone processes and biogeochemical cycles, and, of course, (3) the role of anthropic activities, such as the utilization of thermal waters for geothermal energy production and thermal tourism, which is a valuable asset for SIDS of the volcanic type.

Since geodiversity is closely linked to biodiversity, only a holistic approach can deliver an understanding of natural processes and distributions and therefore the proper management and conservation of the whole environment. This means that decision-makers should 
promote a comprehensive and integrated approach to nature conservation adapted for SIDS, particularly volcanic ones like Guadeloupe, in the frame of a sustainable and resilient socio-economic-environmental approach. By using the Guadeloupe example, we discussed how this can go through the constitution of a total observatory for all-natural risks affecting SIDS. Activities around the total observatory are essential to boost preparedness, which is essential to mitigate future shocks in small territories with limited technical resources and then limited engineering resilience (Holling, 1996 [108]). These activities should involve not only professional researchers but also local communities and tourists, fostering the integrated plan for sustainable development and the alliance for bulk resilience of the territory. Science could greatly benefit of this alliance that should include participatory environmental monitoring (PEM), in which citizens and tourists contribute to data collection and field observations.

Much like ecotourism, volcano-based tourism around La Soufrière de Guadeloupe incorporates the concept of sustainable tourism in that destinations should be achievable but remain unspoiled for future generations (Lew, 2002 [13]). It consequently follows that any emergency policy and planning must deal with geotourism empowerment, otherwise a significant segment of the population at risk will be overlooked and a major social and economic stimulus underestimated (Karkut, 2010 [126]).

The elements that we furnish in this study should be in future considered to promote resilience policies integrating a sustainable and circular (i.e., regenerative) model for socio-economic empowerment focusing on the volcanic-hydrothermal assets of a SIDS. Circularity is in fact the cornerstone for development of SIDS, where tourism, geothermal and other renewable sources have a crucial role to play, particularly in case of volcanic islands. The transition from linear to circular business models shall be based on a more comprehensive approach to human capital in knowledge and research and development, for a better exploration of resources and risk mitigation, includng preparedness. This approach could be extended to surrounding islands of the Lesser Antilles arc, in an interCaribbean circular effort fostering sustainability and resilience, given the common heritage (including the geoheritage) and the physiographical context which makes the arc and its proximal space a kind of regional sea, such as the Mediterranean one.

Author Contributions: Conceptualization, R.M.; methodology, R.M.; formal analysis, R.M., S.M., D.J. and C.G.; investigation, R.M., S.M., D.J., C.G., V.R. and S.D.; resources, data curation, R.M., S.M., D.J., C.G., V.R. and S.D.; writing-original draft preparation, R.M.; writing-review and editing, R.M., S.M., D.J. and C.G.; visualization, R.M.; supervision, R.M. All authors have read and agreed to the published version of the manuscript.

Funding: This research received no external funding.

Acknowledgments: The authors thank Conseil Departmental 971 and the Office de l'Eau 971 for financial support in the frame of the OE971-IPGP agreement. Federica Sarno is warmly thanked for help with figures. This study contributes to the IdEx Université de Paris ANR-18-IDEX-0001.

Conflicts of Interest: The authors declare no conflict of interest.

\section{References}

1. De Wever, P.; Alterio, I.; Egoroff, G.; Cornée, A.; Bobrowsky, P.; Collin, G.; Duranthon, F.; Hill, W.; Lalanne, A.; Page, K.N. Geoheritage, a National Inventory in France. Geoheritage 2015, 7, 205-247. [CrossRef]

2. Chauvet, M.; Bourdon, E.; Bès de Berc, S.; Legendre, L.; Mompelat, J.-L. Un inventaire pilote des sites géologiques remarquables de Guadeloupe. In Découvrir le Patrimoine Géologique de la France; Géosciences: Ardeche, France, 2008; pp. 176-181.

3. Brocx, M.; Semeniuk, V. Geoheritage and geoconservation-history, definition, scope and scale. J. R. Soc. West. Aust. 2007, 90, 53-87.

4. Bès de Berc, S.; Chauvet Lebrun, J.F.; Léticée, J.L.; Randrianasolo, A.; Traineau, H. Inventaire des Sites Géologiques Remarquables de la Guadeloupe (Phase 2)—Rapport Final. BRGM Report BRGM/RP-55737-FR. 2007, p. 75. Available online: https:/ /dokumen. tips/documents/inventaire-des-sites-geologiques-remarquables-de-la-guadeloupe-.html (accessed on 25 August 2021).

5. Bézèlgues-Courtade, S.; Bes-De-Berc, S. Inventaire et Caractérisation des Sources Thermales de Guadeloupe, Rapport Final; Report BRGM/RP-55060-FR; BRGM: Orléans, France, 2007; p. 116.

6. Conseil Régional de Guadeloupe. Atlas des Paysages de L'archipel Guadeloupe; Deal de Guadeloupe: Guadeloupe, France, 2013. 
7. De Wever, P.; Egoroff, G.; Cornée, A.; Lalanne, A. Géopatrimoine en France. Mém. H.S. Soc. Géol. Fr. 2014, 14, 180.

8. Mazabraud, Y. Historical and Contemporary Use of Natural Stones in the French West Indies. Conservation Aspects and Practices. Sustainability 2019, 11, 4566. [CrossRef]

9. Feuillet, N.; Manighetti, I.; Tapponnier, P. Arc parallel extension and localization of volcanic complexes in Guadeloupe, Lesser Antilles. J. Geophys. Res. 2002, 107, 2331. [CrossRef]

10. Rosas-Carbajal, M.; Komorowski, J.-C.; Nicollin, F.; Gibert, D. Volcano electrical tomography unveils edifice collapse hazard linked to hydrothermal system structure and dynamics. Sci. Rep. 2016, 6, 29899. [CrossRef]

11. Brothelande, E.; Finizola, A.; Peltier, A.; Delchera, E.; Komorowski, J.-C.; Di Gangi, F.; Borgogno, G.; Passarella, M.; Trovato, C.; Legendre, Y. Fluid circulation pattern inside La Soufrière volcano (Guadeloupe) inferred from combined electrical resistivity tomography, self-potential, soil temperature and diffuse degassing measurements. J. Volcnol. Geotherm. Res. 2014, 288, 105-122. [CrossRef]

12. Turner, S. Promoting UNESCO Global Geoparks for sustainable development in the Australian-Pacific region. Alcheringa Australas. J. Palaeontol. 2006, 31, 351-365. [CrossRef]

13. Lew, A. Geotourism and what geographers do. Tour. Geogr. 2002, 4, 347-348. [CrossRef]

14. Buckley, R. Environmental Inputs and Outputs in Ecotourism: Geotourism with a Positive Triple Bottom Line? J. Ecotour. 2003, 2, 76-82. [CrossRef]

15. Kim, S.; Kim, M.; Park, J.; Guo, Y. Cave tourism: Tourists' characteristics, motivations to visit, and the segmentation of their behavior. Asia Pac. J. Tour. Res. 2008, 13, 299-318. [CrossRef]

16. Dowling, R.; Newsome, D. Geotourism: Definition, characteristics and international perspectives. In Handbook of Geotourism; The Geologists' Association: London, UK, 2018; pp. 1-22. [CrossRef]

17. Oikawa, T.; Yoshimoto, M.; Nakada, S.; Maeno, F.; Komori, J.; Shimano, T.; Takeshita, Y.; Ishizuka, Y.; Ishimine, Y. Reconstruction of the 2014 eruption sequence of Ontake Volcano from recorded images and interviews. Earth Planets Space 2016, 68, 79. [CrossRef]

18. Lim, Z.Y.; Flaherty, G. Fiery eruptions: Travel health risks of volcano tourism. J. Travel Med. 2020, 27. [CrossRef]

19. Moretti, R.; Komorowski, J.-C.; Ucciani, G.; Moune, S.; Jessop, D.; de Chabalier, J.-B.; Beauducel, F.; Bonifacie, M.; Burtin, A.; Vallée, M.; et al. The 2018 unrest phase at La Soufrière of Guadeloupe (French West Indies) andesitic volcano: Scrutiny of a failed but prodromal phreatic eruption. J. Volcanol. Geotherm. Res. 2020, 393, 106769. [CrossRef]

20. Préfet de la Région Guadeloupe. 2021. Available online: http:/ / www.guadeloupe.developpement-durable.gouv.fr/IMG/pdf/ dp_journees_japonaises_21062021.pdf (accessed on 30 September 2021).

21. Andrews, G.R. Why the Volcano Erupting in the Caribbean has such a Deadly Reputation. National Geographic. 2021. Available online: www.nationalgeographic.com/science/article/why-st-vincent-volcano-erupting-in-caribbean-has-such-adeadly-reputation (accessed on 30 September 2021).

22. Chanteur, B.; Reif, X. Recensement de la population en Guadeloupe; Insee Flash, 142; Insee: Paris, France, 2020 ; pp. $2416-8211$.

23. Boudon, G.; Komorowski, J.-C.; Villemant, B.; Semet, M.P. A new scenario for the last magmatic eruption of La Soufrière of Guadeloupe (Lesser Antilles) in 1530 A.D. Evidence from stratigraphy radiocarbon dating and magmatic evolution of erupted products. J. Volcanol. Geotherm. Res. 2008, 178, 474-490. [CrossRef]

24. Samper, A.; Quidelleur, X.; Komorowski, J.C.; Lahitte, P.; Boudon, G. Effusive history of the grande decouverte volcanic complex, southern basse-terre (guadeloupe, french west indies) from new k-ar cassignol-gillot ages. J. Volcanol. Geotherm. Res. 2009, 187, 117-130. [CrossRef]

25. Blanc, F. Corrélations chronologiques et géochimiques des formations volcaniques du sud de la Basse-Terre de Guadeloupe (Petites Antillesl), Début du cycle récent. Ph.D. Thesis, Université Scientifique et Médicale de Grenoble, Grenoble, France, 1983; p. 17.

26. Carlut, J.; Quidelleur, X.; Courtillot, V.; Boudon, G. Paleomagnetic directions and K/Ar dating of 0 to 1 Ma old lava flows from La Guadeloupe Island (French West Indies): Implications for time averaged field models. J. Geophys. Res. 2000, 105, 835-849. [CrossRef]

27. Carlut, J.; Quidelleur, X. Absolute paleointensities recorded during the Brunhes chron at La Guadeloupe island. Phys. Earth Planet. Inter. 2000, 120, 255-269. [CrossRef]

28. Samper, A.; Quidelleur, X.; Lahitte, P.; Mollex, D. Timing of effusive volcanism and collapse events within an oceanic arc island: Basse-Terre, Guadeloupe archipelago (Lesser Antilles). Earth Planet Sci. Lett. 2007, 258, 175-191. [CrossRef]

29. Legendre, Y. Reconstruction Fine de L'histoire Eruptive Et Scenarii Eruptifs à la Soufrière de Guadeloupe: Vers un Modèle Intégré de Fonctionnement du Volcan. Ph.D. Thesis, Université de Paris, Paris, France, 2012.

30. Komorowski, J.-C.; Boudon, G.; Semet, M.; Beauducel, F.; Anténor-Habazac, C.; Bazin, S.; Hammouya, G. Guadeloupe. In Volcanic Atlas of the Lesser Antilles, Seismic Research Unit; The University of the West Indies: St. Augustine, Trinidad and Tobago, 2005; pp. 65-102.

31. Peruzzetto, M.; Komorowski, J.-C.; Le Friant, A.; Rosas-Carbajal, M.; Mangeney, A.; Legendre, Y. Modeling of partial dome collapse of La Soufrière of Guadeloupe volcano: Implications for hazard assessment and monitoring. Sci. Rep. 2019, 9, 13105. [CrossRef] [PubMed]

32. Dorel, J.; Feuillard, M. Note sur la crise sismo-volcanique à la Soufriére de la Guadeloupe 1975-1977. Bull. Volcanol. 1980, 43, 419-430. [CrossRef] 
33. Feuillard, M.; Allégre, C.J.; Brandéis, G.; Gaulon, R.; Le Mouël, J.L.; Mercier, J.C.; Pozzi, J.P.; Semet, M.P. The 1975-1977 crisis of La Soufriére de Guadeloupe (F.W.I): A still-born magmatic eruption. J. Volcanol. Geotherm. Res. 1983, 16, 317-334. [CrossRef]

34. Labat, J.-B. Voyage aux Iles, Chroniques Aventureuse des Caraïbes 1693-1705; Phebus Libretto: Paris, France, 1993 ; pp. 56-71.

35. Biot Mercier, D. La Guadeloupe-Explication de la Figure, Eruption d'eau. C. R. Acad. Sci. Paris 1837, IV, 651-654.

36. Barabé, L.; Jolivet, J. Les récentes manifestations d'activité de la Guadeloupe (Petites Antilles). Bull. Volcanol. 1958, 19, 143-158. [CrossRef]

37. Hincks, T.K.; Komorowski, J.C.; Sparks, S.R.; Aspinall, W.P. Retrospective analysis of uncertain eruption precursors at La Soufrière volcano, Guadeloupe, 1975-1977: Volcanic hazard assessment using a Bayesian Belief Network approach. J. Appl. Volcanol. 2014, 3, 3. [CrossRef]

38. Komorowski, J.-C.; Hincks, T.; Sparks, R.; Aspinall, W. Improving crisis decision-making at times of uncertain volcanic unrest (Guadeloupe, 1976). Glob. Volcan. Hazards Risk 2015, 255-262. [CrossRef]

39. Le Friant, A.; Boudon, G.; Komorowski, J.-C.; Heinrich, P.; Semet, M.P. Potential Flank-Collapse of Soufrière Volcano, Guadeloupe, Lesser Antilles? Numerical Simulation and Hazards. Nat. Hazards 2006, 39, 381-393. [CrossRef]

40. Salaün, A.; Villemant, B.; Gérard, M.; Komorowski, J.-C.; Michel, A. Hydrothermal alteration in andesitic volcanoes: Trace element redistribution in active and ancient hydrothermal systems of Guadeloupe (Lesser Antilles). J. Geochem. Explor. 2011, 111, 59-83. [CrossRef]

41. Heap, M.J.; Baumann, T.S.; Rosas-Carbajal, M.; Komorowski, J.; Gilg, H.A.; Villeneuve, M.; Moretti, R.; Baud, P.; Carbillet, L.; Harnett, C.; et al. Alteration-Induced Volcano Instability at La Soufrière de Guadeloupe (Eastern Caribbean). J. Geophys. Res. Solid Earth 2021, 126. [CrossRef]

42. Zlotnicki, J.; Boudon, G.; Le Mouël, J.L. The volcanic activity of La Soufriére of Guadeloupe (Lesser Antilles): Structural and tectonic implications. J. Volcanol. Geotherm. Res. 1992, 49, 91-104. [CrossRef]

43. Allard, P.; Hammouya, G.; Parello, F. Dégazage magmatique diffus à la Soufrière de Guadeloupe, Antilles. C. R. Acad. Sci. Ser. IIA Earth Planet. Sci. 1998, 327, 315-318. [CrossRef]

44. Villemant, B.; Hammouya, G.; Michel, A.; Semet, M.P.; Komorowski, J.-C.; Boudon, G.; Cheminée, J.-L. The memory of volcanic waters: Shallow magma degassing revealed by halogen monitoring in thermal springs of La Soufrière volcano (Guadeloupe, Lesser Antilles). Earth Planet. Sci. Lett. 2005, 237, 710-728. [CrossRef]

45. Villemant, B.; Komorowski, J.C.; Dessert, C.; Michel, A.; Crispi, O.; Hammouya, G.; De Chabalier, J.B. Evidence for a new shallow magma intrusion at La Soufrière of Guadeloupe (Lesser Antilles): Insights from long-term geochemical monitoring of halogen-rich hydrothermal fluids. J. Volcanol. Geotherm. Res. 2014, 285, 247-277. [CrossRef]

46. Villemant, T.; Marini, L.; Hunziker, J.C. Geochemistry of the thermal springs and fumaroles of Basse-Terre Island, Guadeloupe, Lesser Antilles. Bull. Volcanol. 2000, 61, 477-490. [CrossRef]

47. Allard, P.; Aiuppa, A.; Beauducel, F.; Gaudin, D.; Di Napoli, R.; Calabrese, S.; Parello, F.; Crispi, O.; Hammouya, G.; Tamburello, G. Steam and gas emission rate from La Soufriere volcano, Guadeloupe (Lesser Antilles): Implications for the magmatic supply during degassing unrest. Chem. Geol. 2014, 384, 76-93. [CrossRef]

48. OVSG-IPGP (1999-2021) Bilan Mensuel de L'activité Volcanique de la Soufrière et et de la Sismicité Régionale. Available online: http:/ / www.ipgp.fr/fr/ovsg/bulletins-mensuels-de-lovsg (accessed on 30 September 2021).

49. Mastin, L.G. Thermodynamics of gas and steam-blast eruptions. Bull. Volcanol. 1995, 57, 85-98. [CrossRef]

50. Jessop, D.E.; Moune, S.; Moretti, R.; Gibert, D.; Komorowski, J.-C.; Robert, V.; Heap, M.J.; Bosson, A.; Bonifacie, M.; Deroussi, S.; et al. A multi-decadal view of the heat and mass budget of a volcano in unrest: La Soufrière de Guadeloupe (French West Indies). Bull. Volcanol. 2021, 83, 1-19. [CrossRef]

51. Sanjuan, B.; Bouchot, V.; Gadalia, A.; Traineau, H. Géothermie haute température: Le dé énergétique. Géosciences 2011, 2011, 32-41.

52. Office de l'Eau 971. Eau et Assainissement: Les Chiffres Clés; Office de l' Eau Guadeloupe: Gourbeyre, France, 2020; 60p.

53. Raguenel, M.; Driesner, T.; Bonneau, F. Numerical modeling of the geothermal hydrology of the Volcanic Island of Basse-Terre, Guadeloupe. Geotherm. Energy 2019, 7, 28. [CrossRef]

54. Chaperon, P.; L'Hote, Y.; Vuillaume, G. Les ressources en eau de surface de la Guadeloupe. Cahier ORSTQM Ser. Hydrologie 1983, XX, 149-178.

55. Dessert, C.; Lajeunesse, E.; Lloret, E.; Clergue, C.; Crispi, O.; Gorge, C.; Quidelleur, X. Controls on chemical weathering on a mountainous volcanic tropical island: Guadeloupe (French West Indies). Geochim. Cosmochim. Acta 2015, 171, 216-237. [CrossRef]

56. Allemand, P.; Delacourt, C.; Lajeunesse, E.; Devauchelle, O.; Beauducel, F. Erosive effects of the storm Helena (1963) on Basse Terre Island (Guadeloupe-Lesser Antilles Arc). Geomorphology 2014, 206, 79-86. [CrossRef]

57. Plaisir, J.; Démonio, W.; Claudin, J. Atlas du Parc National de Guadeloupe; Ministère de l'Ecologie et du Développement Durable: Guadeloupe, France, 2003.

58. Rad, S.D.; Allègre, C.J.; Louvat, P. Hidden erosion on volcanic islands. Earth Planet. Sci. Lett. 2007, 262, 109-124. [CrossRef]

59. Gaillardet, J.; Rad, S.; Rive', K.; Louvat, P.; Gorge, C.; Allegre, C.-J.; Lajeunesse, E. Orography-driven chemical denudation in the Lesser Antilles: Evidence for a new feed-back mechanism stabilizing atmospheric CO. Am. J. Sci. 2011, 311, 851-894. [CrossRef]

60. Saurel, J.-M.; Corbeau, J.; Deroussi, S.; Didier, T.; LeMarchand, A.; Moune, S.; Lynch, L.; Lejeune, A.-M.; Moretti, R.; Komorowski, J.-C. Building a Natural-Hazard-Resilient High-Quality Seismic Network: How WI Network Sustained Hurricanes Maria and Irma. Seism. Res. Lett. 2020, 92, 77-84. [CrossRef] 
61. Thinon, I.; Guennon, P.; Bitri, A.; Truffert, C. Study of the Bouillante Bay (West Basse-Terre Island shelf): Contribution of geophysical surveys to the understanding of the structural context of Guadeloupe (French West Indies-Lesser Antilles). Bull. Soc. Geol. France 2010, 181, 51-65. [CrossRef]

62. Bouchot, V.; Traineau, H.; Sanjuan, B.; Gadalia, A.; Guillou-Frottier, L.; Thinon, I.; Fabriol, H.; Bourgeois, B.; Baltassat, J.M.; Pajot, G.; et al. Modèle Conceptuel du Champ Géothermique haute Temperature de Bouillante, Gaudeloupe, Antilles Franaises. Rapport Final; BRGM-Rapport RP-57252-FR; BRGM: Orléans, France, 2009; p. 60.

63. Calcagno, P.; Bouchot, V.; Thinon, I.; Bourgine, B. A new 3D fault model of the Bouillante geothermal province combining onshore and offshore structural knowledge (French West Indies). Tectonophysics 2012, 526-529, 185-195. [CrossRef]

64. Moeck, I.S. Catalog of geothermal play types based on geologic controls. Renew. Sustain. Energy Rev. 2014, 37, 867-882. [CrossRef]

65. Jeremie, J.J.; Pascaline, H. Les Ressources Hydrothermales et le Thermalisme en Guadeloupe et Martinique; Association pour la Promotion du Thermalisme aux Antilles, PRIM: Pointe à Piitre, Guadaloupe, 1992; p. 47.

66. Ruzié, L.; Aubaud, C.; Moreira, M.; Agrinier, P.; Dessert, C.; Gréau, C.; Crispi, O. Carbon and helium isotopes in thermal springs of La Soufrière volcano (Guadeloupe, Lesser Antilles): Implications for volcanological monitoring. Chem. Geol. 2013, 359, 70-80. [CrossRef]

67. Rivé, K.; Gaillardet, J.; Agrinier, P.; Rad, S. Carbon isotopes in the rivers from the Lesser Antilles: Origin of the carbonic acid consumed by weathering reactions in the Lesser Antilles. Earth Surf. Process. Landf. 2013, 38, 1020-1035. [CrossRef]

68. Bourdon, E.; Bès de Berc, S.; Traineau, H.; Sanjuan, B.; Chauvet, M.; Hervé, J.-Y.; Miehe, J.-M.; Bézèlgues-Courtade, S. Inventaire des Ressources Géothermiques Potentielles de la Guadeloupe—Rapport Final; Report BRGM-56631-FE; BRGM: Orléans, France, 2008; p. 171.

69. Lachassagne, P.; Maréchal, J.-C.; Sanjuan, B. Hydrogeological model of a high-energy geothermal field (Bouillante area, Guadeloupe, French West Indies). Hydrogeol. J. 2009, 17, 1589-1606. [CrossRef]

70. Traineau, H.; Sanjuan, B.; Beaufort, D.; Brach, M.; Castaing, C.; Correia, H.; Genter, A.; Herbrich, B. The Bouillante geothermal field (FWI) revisited: New data on the fractured geothermal reservoir in light of a future stimulation experiment in a low productive well. In Proceedings of the 22nd Workshop on Geothermal Reservoir Engineering, Stanford University, Stanford, CA, USA, 27-29 January 1997.

71. Sanjuan, B.; Brach, M. Etude Hydrogéochimique du Champ Géothermique de Bouillante (Guadleoupe); Rapport BRGM 39880; BRGM: Orléans, France, 1997; p. 84.

72. Sanjuan, B. Champ Géothermique de Bouillante (Guadeloupe): Synthèse des Travaux Réalisés en Géochimie Avant; Final Report BRGM/RC51672-FR; BRGM: Orléans, France, 2001; p. 54.

73. Sanjuan, B.; Lasne, E.; Brach, M. Bouillante geothermal fluid: Mixing and water/rock interaction processes at $250{ }^{\circ} \mathrm{C}$. In Proceedings of the 10th Water-Rock Interaction (WRI-10), Cagliari, Italy, 10-15 June 2001; Volume 2, pp. 911-914.

74. Sanjuan, B.; Le Nindre, Y.-M.; Menjoz, A.; Sbai, A.; Brach, M.; Lasne, E. Le Systèmetravaux de Recherche Liés au Développement du Champ Géothermique de Bouillante (Guadeloupe); Rapport Final. BRGM Report BRGM/RP-53136-FR; BRGM: Orléans, France, 2004; p. 166.

75. Traineau, H.; Lasne, E.; Sanjuan, B. Main results of a long-term monitoring of the Bouillante geothermal reservoir during its exploitation. In Proceedings of the World Geothermal Congress, Melbourne, Australia, 19-25 April 2015.

76. Mas, A.; Guisseau, D.; Mas, P.P.; Beaufort, D.; Genter, A.; Sanjuan, B.; Girard, J. Clay minerals related to the hydrothermal activity of the Bouillante geothermal field (Guadeloupe). J. Volcanol. Geotherm. Res. 2006, 158, 380-400. [CrossRef]

77. Tamburello, G.; Moune, S.; Allard, P.; Venugopal, S.; Robert, V.; Rosas-Carbajal, M.; Deroussi, S.; Kitou, G.T.; Didier, T.; Komorowski, J.-C.; et al. Spatio-temporal relationships between fumarolic activity, hydrothermal fluid circulation and geophysical signals at an arc volcano in degassing unrest: La Soufrière of Guadeloupe (French West Indies). Geosciences 2019, 9, 480. [CrossRef]

78. Pedroni, A.; Hammerschmidt, K.; Friedrichsen, H. He, Ne, Ar, and C isotope systematics of geothermal emanations in the Lesser Antilles Islands Arc. Geochim. Cosmochim. Acta 1999, 63, 515-532. [CrossRef]

79. Bernard, M.-L.; Molinie', J.; Petit, R.-H.; Beauducel, F.; Hammouya, G.; Marion, G. Remote and in situ plume measurements of acid gas release from La Soufrière volcano, Guadeloupe. J. Volcanol. Geotherm. Res. 2006, 150, 395-409. [CrossRef]

80. Moretti, R.; Moune, S.; Robert, V.; Jessop, D.E.; Didier, T.; Bonifacie, M.; Komorowski, J.C. Intercomparison of geochemical techniques at La Soufrière de Guadeloupe (FWI) volcano: Their advantages and their limits over a long-standing unrest. Ital. J. Geosci. 2020, 139, 398-412. [CrossRef]

81. Massaro, S.; Dioguardi, F.; Sandri, L.; Tamburello, G.; Selva, J.; Moune, S.; Costa, A. Testing gas dispersion modelling: A case study at La Soufrière volcano (Guadeloupe, Lesser Antilles). J. Volcanol. Geotherm. Res. 2021, 417, 107312. [CrossRef]

82. Jean-Baptiste, P.; Allard, P.; Fourré, E.; Parello, F.; Aiuppa, A. Helium isotope systematics of volcanic gases and thermal waters of Guadeloupe Island, Lesser Antilles. J. Volcanol. Geotherm. Res. 2014, 283, 66-72. [CrossRef]

83. Taran, Y.; Kalacheva, E. Acid sulfate-chloride volcanic waters; Formation and potential for monitoring of volcanic activity. J. Volcanol. Geotherm. Res. 2020, 405, 107036. [CrossRef]

84. Bigot, S.; Boudon, G.; Semet, M.; Hammouya, G. Traçage chimique de la circulation des eaux souterraines sur le volcan de la Grande De'couverte (La Soufriere), Guadeloupe. C. R. Acad. Sci. 1994, 318, 1215-1221.

85. Barat, A. Etude du Rôle des Eaux Souterraines dans le Mécanisme des Eruptions Phréatiques; Application à la Montagne Pelée de Martinique et à la Soufriére de Guadeloupe, Document du BRGM N¹15; BRGM: Orléans, France, 1986. 
86. Lefrançois, E.; Eulin, A.; Coste, M.; Delmas, F.; Gros, O.; Dessert, C.; Robert, M.; Tailamé, A.L. Les Diatomées, Bactéries et archées des Sources Hydrothermales des Antilles Françaises; 35ème Colloque de l'ADLaF Belvaux: Luxembourg, 2016.

87. Gibert, D.; de Bremond d'Ars, J.; Carlus, B.; Deroussi, S.; Ianigro, J.-C.; Jessop, D.; Jourde, K.; Kergosien, B.; Le Gonidec, Y.; Lesparre, N.; et al. Observation of the Dynamics of Hydrothermal Activity in La Soufrière of Guadeloupe Volcano with Joint Muography, Gravimetry, Electrical Resistivity Tomography, Seismic and Temperature Monitoring. In Muography: Exploring Earth's Subsurface with Elementary Particles; Oláh, L., Tanaka, H.K.M., Varga, D., Eds.; Geophysical Monograh Series; American Geophysical Union Wiley: Hoboken, NJ, USA, 2021. [CrossRef]

88. Bonanno, G.; Giudice, R.L.; Pavone, P. Trace element biomonitoring using mosses in urban areas affected by mud volcanoes around Mt. Etna. The case of the Salinelle, Italy. Environ. Monit. Assess. 2011, 184, 5181-5188. [CrossRef]

89. Bourrelly, P. Les Algues d'Eau Douce, Initiation à la Systématique. Tome II: Les Algues Jaunes et Brunes: Chrysophyées, Xanthophycées et Diatomées N; BOUBEE \& Cie: Paris, France, 1981; p. 517.

90. Tudesque, L.; Ector, L. Inventaires des Diatomées Benthiques des Rivières de la Guadeloupe (Campagnes 2000-2001); Rapport Final; Cellule de Recherche en Environnment et Biotechnologies-CREBS: Luxembourg, 2002.

91. Baluska, F.; Mancuso, S. Plant neurobiology: From sensory biology, via plant communication, to social plant behaviour. Cogn. Process. 2009, 10 (Suppl. S1), S3-S7. [CrossRef]

92. Baluska, F.; Mancuso, S. Plants and animals: Wide comparison. In Plant-Environment Interactions from Behavioural Perspective; Baluska, F., Ed.; Springer: Berlin/Heidelberg, Germany, 2009.

93. Gurovich, L.A.; Hermosilla, P. Electric signalling in fruit trees in response to water applications and light-darkness conditions J. Plant Physiol. 2009, 166, 290-300. [CrossRef]

94. Baluška, F. Plant-Environment Interactions: From Sensory Plant Biology to Active Plant Behavior; Springer Science \& Business Media: Cham, Switzerland, 2009.

95. Barlow, P.W. Reflections on 'plant neurobiology'. Biosystems 2008, 92, 132-147. [CrossRef] [PubMed]

96. Baluska, F.; Mancuso, S.; Volkmann, D. Communication in Plants: Neuronal Aspects of Plant Life; Springer: Berlin/Heidelberg, Germany, 2006.

97. Volkov, A.G. Plant Electrophysiology: Signaling and Responses; Springer Science \& Business Media: Cham, Switzerland, 2012.

98. Muthert, L.; Izzo, L.G.; Van Zanten, M.; Aronne, G. Root Tropisms: Investigations on Earth and in Space to Unravel Plant Growth Direction. Front. Plant Sci. 2020, 10, 1807. [CrossRef]

99. Ratsimihara, T.; Ducreux, L.; Clair, L.; Pinson, S. Etude des fonds géochimiques des eaux souterraines et des cours d'eau de Guadeloupe; Rapport Final. Report BRGM/RP-63817-FR; BRGM: Orléans, France, 2014; p. 99.

100. Dickinson, J.L.; Shirk, J.; Bonter, D.; Bonney, R.; Crain, R.L.; Martin, J.; Phillips, T.; Purcell, K. The current state of citizen science as a tool for ecological research and public engagement. Front. Ecol. Environ. 2012, 10, 291-297. [CrossRef]

101. Roy, H.E.; Pocock, M.J.O.; Preston, C.D.; Roy, D.B.; Savage, J.; Tweddle, J.C.; Robinson, L.D. Understanding Citizen Science E Environmental Monitoring; Final Report on Behalf of UK-EOF. NERC; Centre for Ecology \& Hydrology and Natural History Museum: Wallingford, UK, 2012; p. 173.

102. OREC. Chifres Clés de Lénerie 2019. 2020. Available online: www.guadeloupe-energie.gp/chiffre-cles-de-lenergie/publicationsde-lorec/ (accessed on 30 September 2021).

103. Demians D'Archimbaud, J.; Surcin, J. Recherches d'énergie géothermique en Guadeloupe. Bull. BRGM 1976, 4, 365-373.

104. Kamila, Z.; Kaya, E.; Zarrouk, S.J. Reinjection in geothermal fields: An updated worldwide review. Geothermics 2020, 89, 101970. [CrossRef]

105. ADEME. Géothermie en Outre-Mer: Vers l'autonomie énergétique. Ademe Mag. 2020, 139, 6-10.

106. Elbatran, A.H.; Yaakob, O.; Ahmed, Y.; Shabara, H. Operation, performance and economic analysis of low head micro-hydropower turbines for rural and remote areas: A review. Renew. Sustain. Energy Rev. 2015, 43, 40-50. [CrossRef]

107. Regibeau, P.; Rockett, K. Economic analysis of resilience: A framework for local policy response based on new case studies. J. Innov. Econ. 2013, 11, 107. [CrossRef]

108. Holling, C.S. Engineering resilience versus ecological resilience. In Engineering within Ecological Constraints; Schultze, P.C., Ed.; 31-National Academy of Engineering: Washington, DC, USA, 1996.

109. Walker, B.; Holling, C.S.; Carpenter, S.R.; Kinzig, A.P. Resilience, Adaptability and Transformability in Social-ecological Systems. Ecol. Soc. 2004, 9. [CrossRef]

110. Achour, N.; Pantzartzis, E.; Pascale, F.; Price, A.D.F. Integration of resilience and sustainability: From theory to application. Int. J. Disaster Resil. Built Environ. 2015, 6, 347-362. [CrossRef]

111. Marchese, D.; Reynolds, E.; Bates, M.E.; Morgan, H.; Spierre Clark, S.; Linkov, I. Resilience and sustainability: Similarities and differences in environmental management applications. Sci. Total Environ. 2018, 613-614, 1275-1283. [CrossRef]

112. Gary, W.V.; Patil, S.G.; Hugar, L.B. Agricultural Sustainability, Strategies for Assessment; Sage Publications India Pvt Ltd.: New Delhi, India, 2005.

113. Ongaro, T.E.; Komorowski, J.-C.; Legendre, Y.; Neri, A. Modelling pyroclastic density currents from a subplinian eruption at La Soufrière de Guadeloupe (West Indies, France). Bull. Volcanol. 2020, 82, 1-26. [CrossRef]

114. Boudon, G.; Semet, M.P.; Vincent, P.M. Flank failure-directed blast eruption at Soufrière, Guadeloupe, French West Indies: A 3,000 yr old Mt. St. Helens ? Geology 1984, 12, 350-353. [CrossRef] 
115. Barberi, F.; Bertagnini, A.; Landi, P.; Principe, C. A review on phreatic eruptions and their precursors. J. Volcanol. Geotherm. Res. 1992, 52, 231-246. [CrossRef]

116. Christenson, B.; Reyes, A.; Young, R.; Moebis, A.; Sherburn, S.; Cole-Baker, J.; Britten, K. Cyclic processes and factors leading to phreatic eruption events: Insights from the 25 September 2007 eruption through Ruapehu Crater Lake, New Zealand. J. Volcanol. Geotherm. Res. 2010, 191, 15-32. [CrossRef]

117. Kato, A.; Terakawa, T.; Yamanaka, Y.; Maeda, Y.; Horikawa, S.; Matsuhiro, K.; Okuda, T. Preparatory and precursory processes leading up to the 2014 phreatic eruption of Mount Ontake, Japan. Earth Planets Space 2015, 67, 111. [CrossRef]

118. Metcalfe, A.; Moune, S.; Komorowski, J.C.; Kilgour, G.; Jessop, D.E.; Moretti, R.; Legendre, Y. Magmatic Processes at La Soufrière de Guadeloupe: Insights from Crystal Studies and Diffusion Timescales for eruption onset. Front. Earth Sci. $2021,9,78$.

119. Le Gonidec, Y.; Rosas-Carbajal, M.; de Bremond d'Ars, J.; Carlus, B.; Ianigro, J.C.; Kergosien, B.; Gibert, D. Abrupt changes of hydrothermal activity in a lava dome detected by combined seismic and muon monitoring. Sci. Rep. 2019, 9, 3079. [CrossRef] [PubMed]

120. Erfurt-Cooper, P.; Cooper, M. Volcano and Geothermal Tourism: Sustainable Geo-Resources for Leisure and Recreation; Earthscan: London, UK, 2010; p. 378.

121. Erfurt-Cooper, P. Active Hydrothermal Features as Tourist Attractions. Observing the Volcano World: Volcano Crisis Communication; Springer: Cham, Switzerland, 2018; pp. 85-105.

122. Prideaux, B. The need to use disaster planning frameworks to respond to major tourism disasters: Analysis of Australia's response to tourism disasters in 200'. In Safety and Security in Tourism, The Haworth Hospitality; Hall, C.M., Timothy, D.J., Duval, D.T., Eds.; The Haworth Hospitality Press: Binghamton, NY, USA, 2004; pp. 281-298.

123. Santana, G. Crisis Management and Tourism: Beyond the Rhetoric. In Safety and Security in Tourism; Hall, C.M., Timothy, D.J., Duval, D.T., Eds.; The Haworth Hospitality Press: Binghamton, NY, USA, 2004; pp. 299-321.

124. Cooper, M.; Erfurt, P. Tsunamis, earthquakes, volcanism and other problems: Disasters, responses and Japanese Tourism. In Crisis Management and Tourism; Laws, E., Prideaux, B., Chon, K., Eds.; CABI: Wallingford, UK, 2007; pp. $234-251$.

125. Perry, R.W.; Lindell, M. Living with Mt. St. Helens: Human Adjustment to Volcano Hazard; Washington State University Press: Washington, DC, USA, 1990.

126. Karkut, J. Under the volcano-Can sustainable tourism development be balanced with risk management. In Volcano and Geothermal tourism: Sustainable Geo-Resources for Leisure and Recreation; Earthscan: London, UK; Washington, DC, USA, 2010 ; pp. $233-246$. 